한국심리학회지: 산업 및 조직

Korean Journal of Industrial and Organizational Psychology

2016. Vol. 29, No. 2, 203-232

\author{
정서노동 상황에서 \\ 서비스 접점 종업원들의 대인관계 강점이 \\ 행복에 미치는 영향* \\ 박 선 희 \\ 서울대학교 심리학과 \\ 이 지 영 ${ }^{+}$ \\ 국방대학교 국방관리대학원
}

긍정심리학의 발전과 함께 성격강점에 대한 실증적 연구들이 이루어지고 있음에도 불구하고, 조직에서의 성격강점에 대한 경험적 연구는 여전히 부족한 실정이다. 본 연구에서는 성격강점 가운데에서도 서비스접 점 종업원들에게 중요한 요소로 여겨지는 대인관계 강점에 초점을 맞추어, 대인관계 강점이 정서적 측면 의 행복인 긍정정서에 미치는 주 효과와 조절효과를 실증적으로 검증하였다. 129 명의 수입전자제품 전시 장과 수리 서비스센터 접수원들을 대상으로 설문을 실시한 결과, 인구통계학적 변인과 다른 성격강점들을 통제한 후에도 대인관계 강점은 행복에 유의한 정적 영향을 나타내 정서 노동 상황에서 대인관계 강점이 행복에 중요한 역할을 하고 있음이 검증되었다. 또한, 대인관계 강점이 정서노동 수행방식(내면행위, 표면 행위)과 행복 간의 관계를 조절하는지 살펴본 결과에서 대인관계 강점은 정서노동 내면행위와 행복 간의 관계에서만 조절효과를 나타냈다. 즉, 정서노동자가 고객에게 행하는 정서를 자신의 실제 정서로 인정하 여 적극적으로 실천하는 내면행위를 할 때 대인관계 강점을 보유하고 있는 종업원들은 그렇지 않은 종업 원에 비해 더욱 긍정정서를 느끼는 것으로 나타났다. 이 결과는 정서노동자들의 행복에 있어 대인관계 강 점이 중요함을 확인시켜 주는 것으로 개인과 조직에게 실무적 시사점을 제공해주고 있다. 결과에 대한 자 세한 시사점, 한계점 및 향후방향은 마지막 논의에 제시하였다.

주요어 : 서비스접점, 정서노동, 대인관계 강점, 행복, 조절효과

* 본 논문은 2015년 대한민국 교육부와 한국연구재단의 지원을 받아 수행된 연구임 (NRF-2015S1A5B5A01015985)

귀중한 조언을 해주신 익명의 심사위원들께 감사드립니다.

† 교신저자 : 이지영, 국방대학교 국방관리대학원 리더십전공 연구교수, joyice94@gmail.com 
‘왕 상무 라면', '땅콩 회항', ‘백화점 갑질 고 객' 사건 등은 직원의 서비스 질에 만족하지 못해 직원에게 무리한 요구를 하여 사회적 물 의를 일으킨 사례로서, 이는 서비스 직원의 정서노동 어려움을 상기시키는 계기가 되었다. 서비스 산업이 계속 확대되고 있는 지금의 조 직 환경 속에서 서비스의 질은 조직의 생산성 증대와 기업의 수익성 측면에서 중요한 역할 을 하는 조직생존의 핵심요인으로 부각되고 있다(Ghobadian, Speller \& Jones, 1994; Lewis, 1989). 서비스의 질이란 상품 자체의 품질을 넘어 고객의 다양한 요구에 부응하는 것이기 때문에, 대부분이 고객과의 접점에 있는 정서 노동 종업원으로부터 제공된다(이랑, 김완석, 신강현, 2006). 이로 인해, 조직의 실무자들1)과 연구자들은 무엇이 정서노동자들의 서비스 질 향상을 가져오게 할 것인가에 답하기 위해 계 속적으로 노력하고 있으며, 본 연구에서는 이 에 대한 답의 하나로 정서 노동자의 대인관계 강점과 행복에 주목하고자 하였다.

성격강점(character strengths)2이란 사고, 정서, 행동에 반영되어 있는 개인의 긍정적 특질(임 영진, 2010)을 말한다. Peterson과 Seligman(2004) 에 의해 24개 성격강점 분류체계(Value in Action: 이하 VIA)가 개발된 이후, 성격강점은 임상, 상담, 교육학을 비롯한 여러 분야에 적 용되며 국내외적으로 활발한 연구가 진행되고 있다. 예를 들어, 김지영(2011)은 성격강점과

1) '고객 갑질' 논란에 $\cdots$ 백화점업계, 직원관리 어쩌 나, 블랙컨슈머 사전 대응 지침 교육, 힐링 공간. 전문 상담 등 사후 서비스도 제공, $\mathrm{EBN}, 2014$ 년 10 월 20일

2) character strength는 임영진(2010), 김지영, 권석만 (2013) 등의 국내 선행연구에 의거해 '성격강점' 으로 번역하여 사용
성격장애, 안녕감 및 우울 간의 관계를 탐색 함으로써 임상장면에서 성격강점을 적용하였 으며, 이현영과 김경원(2010)은 규칙적인 운동 참여자의 성격강점을 확인함으로써 스포츠장 면에서 성격강점의 유용성을 살펴보았다. 이 처럼 성격강점이 주목을 받는 이유는 성격강 점의 발현과 활용이 개인의 행복과 깊은 관 련이 있으며, 또한 Big 5 등과 같은 타고난 개인 성격 특성에 비해 성격강점은 개발과 증진 가능성이 높다고 제안되고 있기 때문이 다(Peterson \& Seligman, 2004).

그러나 이러한 실용적 유용성에도 불구하 고, 지금까지 조직 연구에서 성격강점에 대한 실증적 연구는 국내외적으로 거의 드물었다. Wright과 Wright(2002)을 비롯한 몇몇 연구자 들이 조직에서 성격강점 연구의 필요성을 이 론적으로 제안하고(Wright \& Goodstein, 2007). 최근 들어 성격강점에 대한 경험적 연구들이 이루어지고는 있으나(Harzer \& Ruch, 2012, $2013,2015)$ 여전히 성격강점에 대한 조직에 서의 탐색은 부족하다 할 수 있다. 더욱이 다 른 학문분야와는 대조적으로 국내 조직에서 의 성격강점에 대한 연구는 거의 이루어지지 않았다.

따라서, 이러한 요구에 부응하여 본 연구에 서는 조직 장면 가운데에서도 정서노동 상황 에 초점을 맞춰, 정서노동자들의 성격강점이 행복에 어떠한 영향을 미치는지를 실증적으로 검증하고자 한다. 특히 본 연구에서는 성격강 점 가운데에서도 대인관계 강점에 주목하여 두 가지 측면에서 대인관계 강점의 효용성을 검토하고자 한다. 첫째, 정서노동을 행하는 종 업원들이 보유한 대인관계 강점이 행복에 미 치는 주 효과를 검증한다. 정서노동을 수행하 는 종업원들은 서비스 접점 상황에서 지속적 
박선희 · 이지영 / 정서노동 상황에서 서비스 접점 종업원들의 대인관계 강점이 행복에 미치는 영향

으로 사람들을 만나 대면하고 상호작용을 해 야 한다(Gabriel, Daniels, Diefendorff, Greguras, 2015). 그러므로 다른 어떠한 강점보다 대인관 계 강점을 보유하는 것이 정서노동자들에게 중요한 요소일 수 있다. 따라서 본 연구에서 는 정서노동자에게 상당한 영향을 미칠 것으 로 예측되는 대인관계 강점에 주목하여, 정서 노동자의 대인관계 강점이 다른 성격강점을 통제한 상황에서도 행복에 영향을 미치는지를 실증적으로 검증하고자 한다.

둘째, 본 연구에서는 대인관계 강점이 정 서노동을 행할 때 조절효과를 나타내는지를 확인하고자 한다. 정서노동자들은 자신의 정 서노동 상황에 대응하여, 표면행위와 내면행 위의 정서노동 수행방식 가운데 하나를 주 로 선택하여 사용한다(권혁기, 박봉규, 2011, p.313; Hochschild, 1983, p.44). 본 연구에서는 정서노동자들이 표면행위 또는 내면행위를 행할 때 대인관계 강점이 어떠한 역할을 하 는지에 주목하고자 한다. 즉, 정서노동의 표 면행위 또는 내면행위가 행복에 미치는 영향 에 있어 대인관계 강점이 이들 관계를 강화 또는 완충하는지를 살펴봄으로써 정서노동 상황에서의 대인관계 강점의 역할을 확인해 보고자 한다.

\section{성격강점과 행복 연구}

‘행복이 삶의 목표라면, 미덕은 행복의 바탕 이다'라는 토머스 제퍼슨의 명언처럼 사람들이 자신의 강점, 즉 탁월함을 발휘하며 사는 것 은 행복한 삶의 바탕이 될 수 있다(권석만, 2008). 이와 일맥상통하게 긍정 심리학에서는 강점을 활용하는 삶이 참된 행복과 만족을 얻게 되는 길이라 설명하고 있다(Peterson \& Seligman, 2004). Peterson과 Seligman(2004)에 따 르면, 성격강점은 그 자체로 선하고, 좋은 것 이며, 다른 것을 이롭게 하는 것이기 때문에, 자신이 보유하고 있는 성격강점을 활용하고 발현하는 것은 자신의 내부의 긍정적 만족을 충족시켜 주어 행복으로 이르게 한다고 제안 하였다.

성격강점과 행복 간의 관계에 대한 이론적 제안은 Peterson과 Seligman(2004)이 VIA체계를 확립하면서 더욱 구체화되고 체계화되었다. $\mathrm{VIA}$ 는 정신 병리를 분류하여 체계화한 DSM (Diagnostic and Statistical Manual of Mental Disorders)과 같이, 시대와 문화를 불문하고 전 세계적으로 발견되는 공통된 긍정 특성을 정 리한 긍정특성 분류체계이다. 이는 6개 덕목/ 미덕(virtue)과 24개 강점(character strength)으로

표 1. 6 개 덕목과 24 개 강점

\begin{tabular}{ccc}
\hline 6개 덕목 & 해당 강점 분류 & 세부 강점 \\
\hline 지혜, 지식 & 인지적 강점 & 창의성, 호기심, 개방성, 학구열, 지혜 \\
\hline 자애/ 인간애 & 대인관계 강점 & 사랑, 친절성, 사회지능 \\
\hline 용기 & 정서적 강점 & 용감성, 끈기, 진실성, 활력 \\
\hline 절제 & 절제적 강점 & 관대성, 겸손, 신중성, 자기조절 \\
\hline 정의 & 시민적 강점 & 시민의식, 공정성, 리더십 \\
\hline 초월 & 초월적 강점 & 심미안, 감사, 낙관성, 유머감각, 영성 \\
\hline
\end{tabular}


구성되어 있으며(김지영, 2014, p.77 참조), 6 개 덕목인 지혜(wisdom), 자애(humanity), 용기 (courage), 절제(temperance), 정의(justice), 초월 (transcendence)에는 각각 3 5개의 하위 강점이 포함되어 있다(표 1).

기존의 성격강점 연구들에서는 연구자들의 목적에 따라 성격강점을 6개 덕목 또는 24개 성격강점을 사용하여 연구하기도 하고(예: 김 현정, 고영건, 2014; 이형양, 이완정, 2012), 때 로는 24개의 강점 가운데 일부의 강점인 용서 (김광수, 2002), 감사(노지혜, 이민규, 2011) 등 의 한 가지 특정 강점에만 초점을 맞춰 연구 를 수행하기도 하였다. 특정 강점에만 초점을 맞췄던, 그렇지 않았던 간에 앞서 언급한대로 기존의 성격강점의 연구들은 대부분이 성격강 점과 행복이 어떠한 관련성이 있는지에 주된 관심을 가지고 연구를 진행하였다(예: 김현정, 고영건, 2014; 임영진, 2010; Harzer \& Ruch, 2013; Peterson et al., 2007).

예를 들어, Peterson 등(2007)의 연구에서는 12,439 명의 미국인과 445 명의 스위스인의 성격 강점과 행복 간의 관계를 비교하여 어떠한 강 점이 공통적으로 그리고 차별적으로 행복과 관련이 있는지를 보여주었다. 국내에서 이루 어진 임영진(2010)의 연구에서는 국내 대학생 의 강점과 삶의 만족도 간의 관계를 살펴봄으 로써 기존의 해외 연구 결과들에서 발견된 성 격강점과 삶의 만족도 간의 관계를 비교하여 제시하였다. 이외에도 여러 연구들에서 24 개 의 성격 강점 가운데 어떠한 강점이 삶의 만 족(정일진, 정재희, 김소영, 김윤나, 김대선, 2014) 및 행복(Gillham et al., 2011; Peterson et al., 2007; 김현정, 고영건, 2014)에 관련성이 있 는지를 검토하고 있다.

비록 조직연구에서 성격강점에 대한 연구가
다른 영역에 비해 많이 이루어지지는 않았지 만, 이들 연구들 역시 기존의 연구들과 마찬 가지로 대부분이 성격강점과 행복 간의 관계 에 관심을 가졌다. 가령, Harzer와 Ruch(2013)는 1,111 명의 조직 구성원들을 대상으로 자신이 보유하고 있는 성격강점이 직무만족, 몰입, 그 리고 의미로운 삶과 어떠한 관련성이 있는지 를 살펴보았으며, Littman-Ovadia와 Steger(2010) 는 직장에 종사하고 있는 종업원들을 대상 으로 성격강점과 심리적 안녕감(psychological well-being)간의 관계를 다룸으로써 조직에서도 성격강점이 행복에 기여하는지를 실증적으로 검증하고자 하였다.

이렇듯 조직 연구를 포함하여 기존의 성격 강점 연구들의 공통점을 살펴보면, 성격강점 은 성격강점의 정의상 행복과 관련성이 깊기 때문에 대상이 다름에도 불구하고 24 개의 강 점 가운데 많은 수가 행복과 관련이 있었다. 예를 들어, 국내 대학생 309명을 대상으로 실 시한 임영진(2010)의 연구에서는 겸손을 제외 한 23 개의 성격강점이 삶의 만족으로 측정한 행복과 유의한 정적상관이 있었으며, 예비 유 아교사들을 대상으로 한 김성숙(2012)의 연구 에서도 겸손을 제외한 23 개의 성격강점이 행 복과 유의한 정적관계를 나타냈다.

하지만 이러한 공통점에도 불구하고, 성격 강점은 대상에 특성에 따라 삶의 만족 또는 긍정정서와 같은 행복 간의 관계에 있어 특정 강점이 다른 강점에 비해 더 강한 상관을 보 이고 있었다. 예컨대, 예비 유아교사들 226 명 을 대상으로 실시한 김성숙(2012)의 연구에서 는 24개 성격강점 가운데 사회지능, 감사, 호 기심이 그 순서대로 다른 성격강점에 비해 유 의하게 행복과 강한 정적 상관을 나타냈으며, 국내 대학생들의 성격강점과 행복간의 관계를 
다룬 김지영(2011)의 연구에서는 낙관성, 끈기, 용감성이 .40 이상의 높은 상관을 보이며 심 리적 안녕감과 강한 정적 상관을 나타냈다.

이러한 연구적 흐름을 반영하여, 본 연구에 서는 조직에 종사하고 있는 정서노동자들의 성격강점 가운데 어떠한 성격강점이 다른 강 점에 비해 더 강하게 나타날까에 관심을 가지 고 이에 답하고자 한다.

\section{정서노동자의 대인관계 강점이 행복에 미치는 영향}

그렇다면 정서노동을 수행하는 사람들은 어떠한 강점을 보유하고 있을까? 서비스업에 서 정서노동을 하는 종업원들은 조직과 고객 이 연결되는 위치에서 고객에게 조직을 대 표하는 역할을 수행한다(Brown, Gummersson, Edvardsson, \& Gustavsson, 1991). 따라서 정서노 동자들은 대개 고객과의 대면상호작용을 하게 되고, 이때 고객의 반응에 따라 그때그때 대 처하는 것이 서비스의 질로 연결되게 된다. 즉, 고객은 종업원과의 상호작용을 통해 서비 스의 질을 지각하게 된다(Bowen \& Schneider, 1988). 이러한 대면작용의 특징 때문에, 기존 의 정서노동 연구에서는 고객과의 상호작용 과 관련된 개인차 변인인 외향성(extravert)과 호의성(agreeableness) 등에 주목하여, 이것이 정서노동과 높은 관련성이 있음을 검증하였 다(Kiffin-Petersen, Jordan, \& Soutar, 2011; 신강현 외, 2006). Kiffin-Petersen 등(2011)에 따르면, 사 교적이고 다른 사람과 이야기 하는 것을 좋아 하는 외향적인 사람들은 상호작용을 통해 긍 정적 경험을 할 것이라 하였으며, 호의적인 사람들은 다른 사람들의 행복에 대해 진심으 로 관심이 많고 신경을 쓰기 때문에 고객의
니즈에 대한 공감을 가져 서비스 질에 기여할 것이라 주장하였다.

대면행동과 관련이 깊은 성격강점으로 대인 관계 강점이 있다. 대인관계 강점(interpersonal character strength)이란 다른 사람을 보살피고 친밀해 지는 것과 관련된 덕목으로서 Park, Peterson과 Seligman(2004)은 대인관계 강점을 자애(humanity)라고 칭하였다. 이는 3 개의 하 위 강점, 사랑(love), 친절성(kindness), 사회지능 (social intelligence)으로 구성되어 있다(Seligman, 2002). 사랑(love)은 다른 사람과의 친밀한 관계 를 소중히 여기고 실천하는 능력을 말하며, 친절성(kindness)은 다른 사람을 위해 호의를 보이고 선한 행동을 하려는 동기와 실천력을 말한다. 마지막으로 사회지능(social intelligence) 은 자신과 다른 사람의 동기와 감정을 잘 파 악할 줄 알고(McGrath, 2015), 다양한 사회적 상황에 적절히 처신할 수 있는 능력을 의미 한다.

대인관계 강점의 사랑, 친절성, 사회지능은 사람들 간의 관계, 대면관계 속에서 강점을 발휘하는 것이기 때문에, 기존의 정서노동 연 구에서 많이 다루어져온 개인특성 변인인 외 향성(신강현, 이랑, 허창구, 김재연, 2006), 호 의성(신강현 외, 2006) 및 정서지능(백승근, 신 강현, 허창구, 2011)과 깊은 관련성이 존재한 다 할 수 있다. 즉, 다른 사람과의 관계에 관 심이 많고, 타인을 배려하고, 타인의 감정과 정서를 잘 인지, 파악하여, 표현하는 능력은 다른 사람들을 사랑하고, 호의를 베풀고, 타인 과의 관계에서 탁월한 대처능력을 갖춘 대인 관계 강점과 많은 공통점이 존재한다 할 수 있다.

대인관계 강점은 VIA의 개발 이후 다양한 성격강점들 중 행복과 보다 긴밀히 관련이 있 
는 성격강점으로 중요하게 다뤄지고 있다. 인 간의 행복과 성숙에 관해 연구한 저명한 심 리학자들(Allport, 1955; Fromm, 1947, Maslow, 1968, 1971; Ryff, 1989)은 긍정적인 인간관계를 행복에 필수적 요소로 언급하며 주관적 안녕 을 가장 일관성 있게 잘 예측하는 요인으로 인간관계를 제안하고 있다(Diener, 2001). 국내 에서도 대인관계 강점이 가지는 의미와 영향 에 대한 연구가 진행되고 있다. 여러 경험적 연구들에서는 성격강점 중, 사랑, 친절성 등이 개인의 적응, 행복, 안녕에 긍정적인 영향을 미침을 보여주고 있다(김광은 등, 2010; 박미 진, 2007). 예를 들면, 사관생도를 대상으로 성 격강점과 행복과의 관계를 살펴본 김광은 등 (2010)의 연구에서는 중다회귀 분석을 통해 낙 관성과 사랑이 행복감을 설명하는 것으로 밝 혀졌다.

그러나 몇몇 연구들이 이와 같이 대인관계 강점의 긍정적 효과를 보여주고는 있으나 고 객들과의 상호작용이 직무에 주요한 요소로 작용하는 정서노동 종업원들에게 있어 대인관 계 강점의 영향력을 규명해 내는 연구는 많지 않다. 본 연구에서는 대면상황 및 대인관계 속에서 유능성을 발휘하는 대인관계 강점이 정서노동 장면에서 다른 성격강점에 비해 구 성원의 행복에 가장 강한 영향을 미칠 것으 로 예상하였다. 대인관계의 중요성은 조직에 서 더욱 핵심적일 수 있다. 조직은 기본적으 로 두 명 이상의 개인들이 목적을 가지고 모 인 집단으로 사람들과의 상호작용은 피할 수 없는 것일 수 있다. 특히 이것은 고객과의 접 전 지점에 있는 정서노동자들에게는 대인관계 자체가 자신의 직무가 된다. 정서노동자는 근 무시간의 대부분을 고객과 직접적인 상호작용 을 하면서 보내기 때문에 대인관계 강점을 보
유한 사람들은 대인관계 속에서 업무가 원활 할 수 있으며, 오히려 대인관계 속에서 긍정 적인 경험을 할 수 있다.

대인관계 강점이 행복에 긍정적 영향을 미 칠 것이라는 이유는 대인관계 강점의 정의에 서도 그 근거를 찾을 수 있다. 비록 조직 구 성원을 대상으로 하여 대인관계 강점이 행복 에 미치는 영향을 직접적으로 본 연구는 거의 없으나, 몇몇 연구들에서 이에 대한 증거를 찾을 수 있다. 공동체의 조직적 생활을 하고 있는 사관생도를 대상으로 성격강점과 행복과 의 관계를 살펴본 김광은 등(2010)의 연구에서 는 사랑이 행복감을 유의하게 설명하는 것으 로 밝혀졌다. 또한, 보육교사 200명을 대상으 로 현재의 성격강점과 보육교사로서 요구되는 성격강점간의 차이를 살펴본 황해익과 탁정화 (2015)의 연구에서 보육교사들은 24 개 강점 가 운데 다른 사람을 보살피고 친밀한 관계를 유 지하는데 필요한 사랑, 친절성, 사회지능의 대 인관계 강점이 다른 강점에 비해 유의하게 높 은 것으로 나타났다. 이에 대해 저자들은 보 육교사들은 영유아와 대면하여 상호작용을 통 해 영유아를 돌보기 때문에 다른 교사에 비하 여 사랑, 친절과 같은 대인관계 강점이 요구 된다고 설명하였다. 이 연구는 정서노동 장면 에서도 적용될 수 있는데, 서비스 접점에서 사람들과 대면하여 서비스를 제공해야 하는 정서노동자 역시 그들의 직무에서 대인관계 강점은 중요할 수 있으며, 또한 이것은 정서 노동자의 행복에 상당한 영향을 미칠 것으로 예상된다. 따라서 본 연구에서는 이와 같은 이론적, 실증적 연구를 바탕으로 다음과 같은 가설을 설정하였다.

가설 1-1. 정서노동자의 대인관계 강점은 
행복에 유의한 정적(+) 영향을 미칠 것이다.

가설 1-2. 정서노동자의 대인관계 강점은 다른 강점에 비해 행복에 가장 강한 정적 $(+)$ 영향을 미칠것이다.

\section{정서노동 수행방식이 행복에 미치는 영향}

서비스업의 비중이 계속적으로 증대되면 서, 정서노동에 대한 연구는 지난 60 여 년 동안 국내외적으로 많은 관심을 받아왔다 (Kammeyer-Mueller, Bubenstein, Long, Odio, Buckman, Zhang, Halvorsen-Ganepola, 2013; Hülsheger \& Schewe, 2011). Hochschild(1983)가 정서노동의 정의 및 개넘을 소개한 이래, 정 서노동 연구는 정서노동의 선행변인(예: 신강 현 외, 2006)과 결과변인(예: 김문숙, 김예실, 이순묵, 2014) 그리고 정서노동의 영향을 완화, 강화시킬 수 있는 조절변인(예: 김원형, 신강 현, 허창구, 이종현, 2007; 박선애, 이재창, 2014; 신강현, 한영석, 김완석, 김원형, 2008)과 매개변인(예: 노혜미, 유태용, 신강현, 2007; 백승근, 신강현, 허창구, 2011)에 대한 탐색까 지 다양한 방향으로 폭넓은 연구가 진행되고 있다.

특히, 기존의 정서노동의 연구에서는 정서 노동의 수행방식에 따라 어떠한 차별적 영향 을 나타내는지에 많은 관심을 가져왔다(예: 김문숙 등, 2014; Hülsheger \& Schewe, 2011). Hochschild(1983)에 따르면, 고객을 대하는 서 비스직 종업원이 정서노동을 수행하는 방식 은 크게 두 가지, 정서노동의 표면행위(surface acting)과 내면행위(deep acting)로 구분할 수 있 다. 표면행위란 고객과의 정서적 응대상황에 서 요구되는 감정을 외적으로 표현하는데 초
점을 맞추는 것으로, 실제 감정의 변화노력이 아니라 외적 표현을 위한 노력으로서 감정 표 현 속에 자신의 진정한 감정을 감추는 것과 관련된다. 반면, 내면행위는 고객 응대에서 적 절한 정서를 나타내기 위해서 표면적인 모습 을 단순하게 드러내 보이기보다는 실제로 자 신의 감정을 변화시켜 정서적 행동을 긍정적 으로 실천하려는 실제적인 노력의 과정을 말 한다(Hochschild, 1983). 이와 유사하게, Grandey (2000)는 표면행위는 관찰 가능한 정서의 '표 현’을 관리하는 것이고 내면행위는 내적 ‘정서' 를 통제하는 것으로 정의하였는데, 그에 따르 면 내면행위는 자신이 보이고 싶어 하는 감정 을 실제로 느끼려고 하는 노력의 결과이기 때 문에 이를 위해 심상 및 사고, 신체적인 형태 의 변화 등에 있어 적극적인 노력이 수반된다 고 설명하였다.

기존의 정서노동 수행방식과 정서노동자의 심리적 안녕에 관한 연구들이 완전히 일관된 결과를 나타낸 것은 아니지만(예, Ashforth \& Humphrey, 1993), 메타분석을 포함한 여러 국 내외 연구들에서는 정서노동의 표면행위는 정 서노동자의 심리적 안녕에 부정적 영향을 미 치는 반면, 정서노동의 내면행위는 심리적 안 넝감에 긍정적 영향을 미치는 것으로 보고하 고 있다. 예를 들어, 서비스, 세일즈, 관리, 판 매, 육체노동 등 다양한 직종으로 구성된 238 명을 대상으로 연구한 Brotheridge와 Grandey (2002)의 연구에서는 표면행위는 개인적 성 취감과 부적관계를 가진 것에 반해 내면행 위는 정적관계를 보여 표면행위와 내면행위 의 상반된 영향에 대한 결과를 보여주었다. 기존의 정서노동 연구 116 개를 메타분석한 Kammeyer-Mueller 등(2013)의 연구에서는 표면 행위는 직무만족에 부적상관을, 스트레스/고갈 
(stress/exhaustion)에 정적상관을 가져 부정적 영 향을 보여주었으나 이와 다르게 내면행위는 직무만족에 정적상관을, 스트레스/고갈에는 부 적상관을 가지며 정서노동자의 심리적 안녕에 긍정적 영향을 나타냈다. 2012년 2월까지 국내 학위논문 및 학술지에 게재된 총 43 개의 연구 들을 메타 분석한 김문숙 등(2014)의 연구에서 도 정서노동의 표면행위는 조직 입장에서의 바람직하지 못한 변수인 정서적 소진, 비인격 화, 그리고 이직의도와 정적 상관을 나타내며 부정적 영향이 있음을 보여주었으나 내면행위 는 비인격화는 부적 상관을, 조직몰입과는 정 적 상관을 나타내 긍정적 영향이 있음을 확인 시켜주었다.

요약하면, 이들 연구들에서는 일관적으로 정서노동의 표면행위는 조직과 개인에게 부정 적 결과를 초래하는 반면 내면행위는 종업원 에게 긍정적 결과를 가져온다고 보고하고 있 다. 그렇다면 왜 정서노동의 두 가지 수행방 식은 다른 결과를 나타내는가? 이에 대해 Cote 와 Margan(2002)은 정서노동의 표면행위는 부 정적 정서의 억제로 인해 부정적 영향이 나타 난다고 설명하였다. 즉, 서비스를 제공해야 하 는 종업원은 정서노동을 행할 때 표현해야 하 는 공적인 정서에 맞도록 자신의 부정적 정서 를 억제하게 되는데, 이는 자신이 발생하는 내적 정서와 불일치를 일으켜 직무만족이 감 소하고 스트레스가 높아진다고 설명하였다. 또한 이 랑 등(2006)에 따르면 정서노동의 표 면행위는 진짜 감정을 억누르려는 심리적 노 력과 내적 긴장으로 인해 개인의 진실한 자기 이미지를 침해하게 되고 또한 장기간 자신의 실제 감정에 반하여 진실하지 않은 행동을 해 야 하기 때문에 이는 자신이 타인의 감정으로 부터 분리된 느낌을 경험하게 되어 정서적 소
진과 스트레스를 경험할 수 있다고 하였다. 내면행위가 심리적 안녕감에 긍정적인 결과 를 나타내는 이유에 대해 이랑 등(2006)은 내 면행위는 실제로 자신의 감정을 변화시켜 적 극적으로 긍정적 실천을 실행하기 때문에 이 는 조직과 고객으로부터 긍정적인 피드백을 받고 스스로 일에 대한 성취감을 얻게 된다고 설명하였다. 이는 자신의 업무에 전념하여 성 공적인 업무 수행을 이뤄 내재적 만족감과 동 기부여를 가능하게 한다는 Hackman과 Oldham (1975)의 직무특성 이론과도 맥을 같이 하는 설명이라 할 수 있다.

본 연구에서는 정서노동의 두 가지 수행방 식이 행복에 미치는 영향이 어떠한지를 살펴 보고자 하였다. 기존의 정서노동 연구에서는 정서노동자의 심리적 안녕감에 대해 오랫동 안 관심을 가져왔으나 대부분의 연구들이 긍 정적 안녕감 보다는 직무소진(burnout), 정서 고갈(emotional exhaustion), 스트레스(stress) 등과 같은 부정적 변인에 주된 초점을 맞춰왔다. 최근 들어 긍정 심리학을 비롯한 긍정적 연구 관점이 강조되기 되면서, 정서노동 연구자들 역시 정서노동의 부정적 측면이 아닌 긍정적 측면이 더욱 부각되어져야 함을 주장하고 있 다(Humphrey, Ashforth, \& Diefendorff, 2015). Humphrey 등(2015)에 따르면, 정서노동이 어렵 고 힘들다는 편견이 있는 일임에도 불구하고 정서노동 종사자들 가운데 많은 사람들이 정 서노동 하는 것을 즐기고 보람 있게 느낀다고 설명하였다(p. 750).

몇몇 연구들이 정서노동자의 행복에 초점을 맞춰, 직접적으로 정서노동이 행복에 미치는 영향을 실증적으로 검증하고자 하였다(유정희, 2010; 차정주, 이효림, 2015). 예를 들어, 유아 교사의 소진과 정서노동이 행복에 미치는 영 
향을 살펴본 차정주와 이효림(2015)에서는 표 면행위는 행복에 유의한 부적영향을, 내면행 위는 행복에 유의한 정적 영향을 나타냄을 보 여주었다. 또한 직접적으로 정서노동의 표면 행위를 검증한 것은 아니나 표면행위와 유사 한 정서적 부조화를 정서노동으로 정의한 유 정희(2010)의 연구에서도 정서적 부조화는 행 복과 유의한 부적관계를 가지는 것으로 나타 났다.

이러한 결과들을 토대로 본 연구에서는 정 서노동의 표면행위와 내면행위는 행복에 다른 영향을 나타낼 것이라 예상하였다. 즉, 정서노 동의 표면행위는 긍정적 심리적 안녕감인 행 복에 부정적 영향을 미치는 반면, 내면행위는 긍정적 영향을 미칠 것이라 예상하였다. 위와 같은 이론적, 실증적 연구를 바탕으로 본 연 구에서는 다음과 같은 가설을 제시하였다.

가설 2-1. 정서 노동자의 표면행위는 행복 에 유의하게 부적(-) 영향을 미칠 것이다. 즉, 표면행위 전략을 많이 사용하는 정서 노동자 는 낮은 행복감을 느낄 것이다.

가설 2-2. 정서 노동자의 내면행위는 행복 에 유의하게 정적(+) 영향을 미칠 것이다. 즉, 내면행위 전략을 많이 사용하는 정서 노동자 는 높은 행복감을 느낄 것이다.

\section{대인관계 강점의 조절효과}

정서노동 연구자들은 정서노동이 조직현장 에서 필수적이라면 어떻게 하면 정서노동으로 인한 부정적 영향을 완화시킬 수 있을지에 관 심을 가지고 정서노동과 직무태도 간의 관계 를 조절, 완충하는 변인을 밝히기 위해 노력
해왔다(예: 김원형 등, 2007; 백승근 등, 2014; 신강현 등, 2008). 기존의 연구들에서 살펴본 개인특성과 관련된 조절변인으로는 성별 등 의 인구통계학적 변인(예: Johnson \& Spector, 2007), 정서지능(예: 신강현 등, 2008), Type A (예: 한주원, 2005), 성격 5요인(예: 신강현 등, 2006; Judge, Woolf, Hurst, 2009), 자기감시(백 승근 등, 2014) 등이 있다. 예컨대, Johnson과 Spector(2007)는 여성이 표면행위에 개입할 때 더욱 부정적인 결과를 경험함을 보여줌으로써 성별이 정서노동과 직무태도간의 관계에 중요 한 조절변인임을 보여주었으며, 박선애와 이 재창(2014)의 연구에서는 정서노동 수행방식이 직무탈진 및 직무열의 미치는 영향에서의 긍 정심리자본의 조절효과를 살펴봄으로써 정서 노동자가 가진 긍정적 심리상태가 어떠한 강 화, 완충 효과를 내는지를 검증하였다.

비록 이들 연구들이 어떠한 개인적 특성이 정서노동에서 차별적 영향을 나타내는지를 밝 혀내기 위해 노력했음에도 불구하고, 개인 특 성 변인에 관한 조절변인 연구는 보완되어야 할 과제들이 존재한다. 우선, 기존 연구에서는 정서노동의 영향을 조절(예: 박선애, 이재창, 2014)하는 다양한 변인들을 발견하고는 있으 나, 동일한 변인을 살펴본 것임에도 불구하여 여전히 일관적이지 않은 결과를 보이고 있다. 예를 들어, 박선애와 이재창(2014)의 연구에서 내면행위는 직무탈진과 유의한 부적관계를 가 졌으나, 차정주, 이효림(2015)의 연구에서는 이 들 관계가 유의한 관계를 갖지 못하였다. 이 는 더 많은 연구를 통해 다양한 변인들의 조 절효과를 검토할 필요성이 있음을 시사한다.

또한, 비록 기존의 정서노동의 연구에서 조 직 환경 및 맥락에 대한 조절변인의 발견(예: 김영조, 한주희, 2008; 박건우 등, 2014)을 통 
해 정서노동자들의 업무환경개선에 힘쓰고 있 으나 정서노동은 다른 어떠한 직무보다 정서 노동자의 행위에 의해서 서비스의 질이 결정 되기 때문에 개인 특성의 영향이 크다 할 수 있다. Kiffin-Petersen 등(2011)은 정서노동과 관 련하여 다양한 조절변인이 밝혀지고 있으나 정서노동과 관련된 개인특성 변인의 조절효과 연구가 다른 연구들에 비해 많은 연구가 이루 어지지 않았음을 지적한바 있다. 실제 조직 환경에서 인재채용, 선발, 그리고 교육의 중요 성이 지속적으로 증가하고 있다는 점을 고려 한다면 기존 연구에서 개발과 성장이 가능한 개인 특성을 발견하여 정서노동 종사자들의 적응 및 업무 성과 향상에 활용하는 것이 더 욱 필요하다 할 수 있다. 이러한 요구에 부응 하여, 본 연구에서는 긍정 심리학의 발전과 함께 그 중요성을 인정받고 있는 성격강점에 초점을 맞춰, 성격강점 가운데 정서노동과 깊 은 관련성이 있다고 여겨지는 대인관계 강점 이 정서노동 수행방식과 행복 간의 관계를 조 절하는지 살펴보고자 하였다.

기존 연구에서 대인관계 강점의 조절효과를 직접적으로 살펴본 연구가 드물기 때문에, 이 에 대한 근거는 대인관계 강점을 비롯한 대인 관계 강점의 하위요소인 사랑, 친절성, 사회지 능과 관련된 변인들의 조절효과에서 찾을 수 있다. 예를 들어, 박미진(2007)은 정서노동과 관련하여 대인관계 강점의 효과를 살펴본 것 은 아니나 여성노인의 스트레스와 우울 지각 에서 대인관계 강점간의 관계를 확인함으로써 대인관계 강점의 효과를 확인시켜 주었다. 즉, 여성 노인이 6개 대표강점 중, 정서 강점이나 동기 강점 보다 대인관계 강점을 많이 지각하 는지에 따라 우울이 스트레스에 미치는 부적 관계가 유의하게 낮음을 보여주었다. 또한, 성
격 5요인과 정서노동 수행방식 간의 관계를 살펴본 신강현 등(2006)의 연구에서는 사회적 행동을 통해서 긍정적인 관계를 개발하고 유 지하려는 호감성(agreeableness)이 정서노동의 내 면행위와 유의한 정적관계가 있음을 검증함으 로써 대인관계 강점의 친절성이 내면행위와 긴밀한 관계가 있음을 보여주었다. 외향성이 정서노동 수행방식과 상태적 정서(state affect) 간의 관계를 조절하는지 검증한 Judge 등 (2009)의 연구에서도 외향성은 표면행위에는 상태적 부적정서(state negative affect)에 완충 효과를, 내면행위에는 상태적 정적정서(state positive affect)에 강화효과를 나타내 유의한 조 절변인임을 보여주었다.

따라서, 본 연구에서도 이와 같은 경험적 연구들의 결과를 바탕으로 대인관계 강점은 정서노동 수행방식이 행복에 미치는 영향에서 조절효과를 나타낼 것이라 예상하였다. 대인 관계 강점은 표면행위 수행에서 오는 심리적 안녕의 부정적 영향을 약화시키며 완충하는 역할을 하리라 기대된다. 대인관계 강점은 대 인에게 친밀하게 다가가 대인적 상호작용을 많이 하고, 호의를 베풀며, 대인관계 상황 대 처 능력(O' Sullivan, et al., 1965)과 관련되기 때 문에 대인관계 강점이 높은 사람은 관계적 상 황에 맞게 자신을 잘 관리하고, 자신의 의사 를 잘 전달할 수 있기 때문에 표면행위로 인 한 스트레스 상황을 효과적으로 대처할 수 있 으리라 여겨진다.

또한, 대인관계 강점은 내면행위가 행복에 미치는 영향에 있어 강화효과를 나타내리라 예상된다. 특성-일치 이론에 따르면, 개인들은 자신들의 특성에 일치하는 방법으로 행동할 때 더 긍정적인 주관적 성과를 경험한다(Bono $\&$ Vey, 2007). 대인관계 강점에 이를 대입해보 
면, 대인관계 강점이 높은 개인들은 대인관계 강점이 활용되는 상황에서도 더욱 긍정적 경 험을 하게 된다. 직업적응이론(work adjustment theory)에서도 개인의 특성과 직무환경 특성의 일치도가 클수록 직무만족이 높아진다고 설명 한다(Dawis \& Lofquist, 1984). 즉, 서비스를 제 공해야 하는 정서노동에서는 고객을 보살피고 배려하는 활동은 필수적이라 할 수 있다. 이 러한 측면에서 대인관계 강점을 가진 사람이 타인을 보살피고 친절하게 대하는 것을 좋아 하고 또 이에 가치를 두는 정서노동을 하는 것은 개인의 특성과 직무환경 간의 일치도가 높은 행동이 되고, 이것이 직원들의 만족감에 영향을 줄 수 있다. 특히 이는 정서노동의 내 면행위에 해당되는 것으로 타인을 보살피고 친절하게 하는 행위가 표면적인 것이 아닌 자 신의 마음과 동일하게 노력을 통해 작용할 때 이는 더 큰 만족감을 줄 것으로 예상할 수 있 다. 따라서 이와 같은 이론적, 실증적 연구를 바탕으로 본 연구에서는 다음과 같은 가설을 제시 하였다.

가설 3-1. 대인관계 강점은 정서노동자의 표면행위와 행복 간의 관계를 조절할 것이다. 즉, 대인관계 강점은 정서노동자의 표면행위 가 행복에 미치는 부적(-) 영향을 더욱 약하게 할 것이다.

가설 3-2. 대인관계 강점은 정서노동자의 내면행위와 행복 간의 관계를 조절할 것이다. 즉, 대인관계 강점은 정서노동자의 내면행위 가 행복에 미치는 정적(+) 영향을 더욱 강하 게 할 것이다.
방 법

연구 대상 및 절차

본 연구의 대상은 고객 서비스의 접점에 있 는 정서노동의 직무 중 하나로서, 고급 수입 전자제품 판매 전시장 접수원 60 명(여성 60명) 과 수리 서비스센터의 접수원 69명(여성 49명, 남성 29명)의 총 129 명을 대상으로 하였다. 전 시장 접수원들의 주요 직무는 고객을 맞이하 고 음료 서비스를 제공하며, 고객이 제품을 관람할 때 고객의 요구에 맞게 편의를 제공하 는 역할을 수행하므로 정서노동자로서의 업무 를 담당하게 된다. 또한 서비스센터의 접수원 은 제품 수리를 의뢰하러 온 고객들을 대상으 로 접수, 음료 및 편의 제공, 고장 증상에 대 한 간단한 설명, 계산 등의 직무를 담당하고 있으므로 많은 경우 화가 난 고객들을 상대로 감정노동을 이행하고 있다. 해당 조직에서는 전시장과 서비스센터 접수원들의 업무가 크게 다르지 않고, 성별 역할에 있어서도 큰 차이 가 있지 않기 때문에, 고객응대를 위한 접수 원 서비스 교육을 조직과 남녀에 관계없이 함 께 실시하며 지속적으로 관리하고 있다. 설문 지는 각 전시장 및 서비스센터의 관리자를 통 하여 해당 조직의 접수원들에게 배부하도록 하였다. 응답의 자유와 개인 비밀유지를 보장 하기 위해, 응답한 설문지는 동봉된 반송용 봉투를 사용하여 각 응답자들이 직접 연구자 에게 보내도록 하였다. 인구통계학적 변수를 비롯한 정서노동, 행복감 등을 측정하였으며, 최종적으로 129 명이 이에 응답하였다. 참가 자의 성별은 여성이 110 명 (85.3\%), 남성이 19명 (14.7\%) 이었으며, 평균 연령은 27.17세 $(\mathrm{SD}=4.36)$, 학력은 전문대졸이 72 명 $(55.8 \%)$ 으 
로 가장 많았으며 대졸이 44명 (34.1\%) 순이었 다. 해당직종의 근속 연수는 평균 1 년 7 개월 $(\mathrm{SD}=2$ 년 3 개월) 이었으며, 근무형태는 정규 직이 90 명 (69.8\%) 으로서 가장 많았다.

\section{도구}

\section{성격강점}

성격강점 척도인 VIA-IS(Values in Action Inventory - Inventory of Strengths)는 Peterson 과 Seligman(2004)에 의해서 개발되었으며, 6 개 미덕(virtue)과 그 하위 24개 강점(character strength)으로 구성되어 있다. Park, Peterson, 및 Seligman(2006)은 미국 50개 주와 54개국에서 117,676 명의 성인을 대상으로 VIA-IS의 범문화 적 안정성을 검증하였다. 이후 McGrath(2015) 역시 75 개 국가 $1,063,921$ 명의 참가자를 대상 으로 같은 결과를 확인하였다. 이들 연구에서 내적 합치도 .70 이상, 검사-재검사 신뢰도도 .70 이상의 안정적 수치를 나타내며, 다양한 연구에서 그 신뢰성과 타당성이 입증되었다 (예: Güsewell \& Ruch, 2012; Müller \& Ruch, 2011; Park, et al, 2006; Peterson, Park, \& Seligman, 2005; Peterson, Park, \& Seligman, 2006).

국내에서는 권석만(2009)이 Peterson과 Seligman(2004)이 개발한 VIA-IS 분류체계를 문 헌과 연구자료 검토 후 248 명의 대학생을 대 상으로 표준화하여 한국어 버전을 제작하였다. 한국 VIA-IS 척도는 총 250 문항으로 구성되어 있으며, 240 문항은 24 개의 강점에 대한 각 10 문항과 나머지 10 개는 문항의 신뢰도 파악을 위한 문항이다. 본 연구에서는 조직에서 이루 어지는 설문지 분량의 제한과 효율성으로 인 해 심리학 전문가 3 인의 소견과 파일럿 테스
트를 거쳐 각 성격강점 당 3 문항을 선택하여 총 72 개 문항을 측정하였다. 본 연구에서는 6 개의 덕목을 기준으로 한 성격강점 분류를 사 용하여 인지적 강점(창의성, 호기심, 개방성, 학구열, 지혜) 15 문항, 대인관계 강점(사랑, 친 절, 사회지능) 9문항, 정서적 강점(용감성, 끈 기, 진실성, 활력) 12 문항, 절제적 강점(관대성, 겸손, 신중성, 자기조절) 12 문항, 정의적 강점 (시민의식, 공정성, 리더십) 9문항, 시민적 강 점(시민의식, 공정성, 리더십), 초월적 강점(심 미안, 감사, 낙관성, 유머감각, 영성) 15 문항이 사용되었다.

6개 요인에 대한 확인적 요인분석 (confirmatory factor analysis) 결과, 모형 전체의 적합도 지수들은 $\mathrm{X} 2=186.13(\mathrm{df}=48), \mathrm{CFI}=.95$, $\mathrm{IFI}=.951, \mathrm{NFI}=.94, \mathrm{RMSEA}=.08$ 로 나타났으며, 상위요인으로부터 6 개의 하위차원에 이르는 경로계수는 모두 통계적으로 유의하여 모델 적합도를 판단하는 적합한 기준을 대체적으로 만족하고 있었다. 내적 합치도는 .65 90의 범 위에 있어 안정적인 수치를 나타냈다. 본 연 구에서 핵심이 되는 대인관계 강점의 예시 문 항으로는 '나는 다른 사람들에게 기쁨을 주는 것을 좋아한다', '친구들은 나에 대해 사교술이 뛰어나다고 평한다' 등이 있으며, '전혀 그렇지 않다' (1) - '매우 그렇다' (5)의 5점 척도로 답 하게 하였다.

정서노동 수행방식

정서노동 수행방식은 표면행위(surface acting) 와 내면행위(deep acting)로 나누어 측정하였다. 내면행위는 Diefendorff 등(2005)의 척도를 황재 선, 신강현, 허창구 및 김동근(2010)이 번안하 여 사용한 정서노동 척도 총 4 개 문항을 평정 하게 하였다. 문항의 예로는 '고객이 나에게 
원하는 감정을 보여주기 위해 실제로 그런 감 정을 가지려고 노력 한다', '다른 사람들에게 나타낼 필요가 있는 감정을 실제로 느끼기 위 해 노력한다', '고객에게 보여주어야 할 감정을 느끼려고 최선을 다한다', '고객에게 보여주어 야 할 감정을 내면으로 만들어 내려고 한다. 각 문항은 1 (전혀 그렇지 않다) 5 (매우 그 렇다) 의 5점 척도로 답하게 하였으며, 내적 합치도는 .73 이었다.

표면행위 또한 Diefendorff 등(2005)의 척도를 황재선 등(2010)이 번안하여 사용한 총 7 개 문 항을 평정하게 하였다. 문항의 예로는 '내 업 무에 알맞은 감정을 표현하기 위해 마치 웃는 가면을 쓰고 일하는 것 같이 행동한다', '고객 에게 서비스할 때 나의 감정을 꾸며서 보여준 다', '실제 내면에서 느끼는 것과는 다른 감정 을 고객에게 보여준다'가 있다. 각 문항은 1
(전혀 그렇지 않다) 5 (매우 그렇다) 의 5점 척도로 답하게 하였으며, 내적 합치도는 .83 이 었다.

행복

본 연구에서는 기존의 행복연구에서 가장 널리 사용되고 있는 주관적 안녕감(subjective wellbeing: Dienner \& Lucas, 1999)의 정서적 측 면만을 측정하였다. 보통, 주관적 안녕감은 삶 의 만족의 인지적 측면과 긍정정서의 정서적 측면을 함께 측정하여 평가(권석만, 2009)하는 것이 일반적이나, 본 연구에서는 조직의 정서 노동 상황에서의 행복이기 때문에 전반적 삶 이 만족이 아닌 특정상황에서 행복을 측정하 는 것이 적합하다 판단하여 상태적 행복에 의거한 정서적 행복만을 분석에 이용하였다. 긍정정서는 Watson, Clark, Tellegen(1988)의

표 2. 측정 변수들의 평균, 표준편차 및 상관계수

\begin{tabular}{|c|c|c|c|c|c|c|c|c|c|c|c|c|c|c|}
\hline 변수 & 평균 & $\begin{array}{l}\text { 표준 } \\
\text { 편차 }\end{array}$ & 1 & 2 & 3 & 4 & 5 & 6 & 7 & 8 & 9 & 10 & 11 & 12 \\
\hline 1. 연령 & 27.17 & 4.36 & 1 & & & & & & & & & & & \\
\hline 2. 학력 & 2.42 & .73 & -.13 & 1 & & & & & & & & & & \\
\hline 3. 조직구분 & .70 & .46 & $.34 * *$ & $-.27 * *$ & 1 & & & & & & & & & \\
\hline 4. 인지적 강점 & 3.41 & .34 & $-.25 *$ & $.19^{*}$ & $-.29 * *$ & 1 & & & & & & & & \\
\hline 5. 대인관계 강점 & 3.62 & .40 & $-.19 *$ & .05 & $-.18 *$ & $.70 * *$ & 1 & & & & & & & \\
\hline 6. 정서적 강점 & 3.57 & .30 & $-.18^{*}$ & .13 & $-.22 *$ & $.86 * *$ & $.84 * *$ & 1 & & & & & & \\
\hline 7. 절제적 강점 & 3.57 & .29 & $-.16 *$ & .14 & $-.20^{*}$ & $.86 * *$ & $.82 * *$ & $.80 * *$ & 1 & & & & & \\
\hline 8. 시민적 강점 & 3.55 & .31 & $-.18^{*}$ & .11 & $-.19 *$ & $.82 * *$ & $.82 * *$ & $.78 * *$ & $.89 * *$ & 1 & & & & \\
\hline 9. 초월적 강점 & 3.62 & .33 & -.14 & .14 & $-.18^{*}$ & $.77 * *$ & $.78 * *$ & $.88 * *$ & $.85^{* *}$ & $.88^{* *}$ & 1 & & & \\
\hline 10. 내면행동 & 3.62 & .61 & $-.27 *$ & $.20^{*}$ & $-.28 *$ & $.52 * *$ & $.43 * *$ & $.53 * *$ & $.53 * *$ & $.52 * *$ & $.47^{* *}$ & 1 & & \\
\hline 11. 표면행동 & 3.10 & .75 & .05 & .04 & .14 & $-.24 * *$ & $-.22 * *$ & $-.23 * *$ & $-.21 * *$ & $-.19 *$ & -.15 & $-.24 * *$ & 1 & \\
\hline 12. 긍정정서 & 3.47 & .57 & $-.19 *$ & $.13^{*}$ & $-.18^{*}$ & $.45 * *$ & $.60 * *$ & $.56 * *$ & $.55 * *$ & $.54^{* *}$ & $.53 * *$ & $.48^{* *}$ & $-.17 *$ & 1 \\
\hline 13. 부정정서 & 2.35 & .73 & .06 & -.07 & .12 & -.16 & -.14 & $-.17 *$ & -.14 & -.13 & $-.15^{*}$ & $-.18^{*}$ & $.21 * *$ & $-.33 * *$ \\
\hline
\end{tabular}


PANAS(positive Affect and negative Affect)를 이현 희, 김은정, 이민규(2003)가 번역하여 타당화한 것을 사용하였다. PANAS는 10 개의 긍정 정서 와 10 개의 부정 정서로 구성되어 있다. 긍정 정서와 부정정서가 한축에 존재하는가 그렇지 않은가에 대한 의견에 따라(Barsade \& Gibson, 2007) 연구자들은 부정정서를 역점수로 전환 하여 긍정정서로 간주하기도 하나(박지연, 손 영화, 2014). 본 연구에서는 긍정정서만의 효 과를 살펴보기 위해 Shin(2014)의 연구에서와 같이 PANAS의 부정 정서를 통제하였다. 지난 일주일 동안 느낀 감정이나 기분의 정도를 5 점 척도 $(1=$ 전혀 그렇지 않다, $5=$ 매우 그렇다) 로 평정하게 하였으며, 긍정 정서의 예시문항 으로는 '즐거운', ‘신나는', ‘활기에 찬', ‘의욕이 넘치는', '확신에 차있는', '상냥한', '활동적인' 이 있으며, 문항 간 신뢰도는 86이었다. 부정 정서의 예시문항으로는 괴로운', ‘혼란스러운' '위축된', ‘수치스러운' 등이 있으며, 문항 간 신뢰도는 86 이었다.

\section{통제변수}

정서노동과 행복에 영향에 줄 것이라고 예 상되는 연령과 학력(고졸 $=1$, 전문대졸 $=2$, 대 졸=3, 기타=4)의 인구통계학적 변인과 대상 조직의 형태를 더미코딩(전시장 $=0$, 서비스센 터=1)하여 조직구분으로 통제하였다.

\section{결 과}

\section{측정변인들의 평균, 표준편차 및 상관관계}

본 연구에 사용된 변수의 평균과 표준편차 및 상관계수는 표 1 에 제시하였다. 인구통계
학적 변인과 성격강점 간의 관계를 살펴보면, 연령은 초월적 강점을 제외하고 모든 강점과 유의한 부적관계(r=-.16 -.25)를 가져 연령이 높아질수록 성격강점의 정도가 낮은 것으로 나타났다. 학력은 인지적 강점과만 유의한 정 적관계 $(\mathrm{r}=.19, \mathrm{p}<.001)$ 를 가졌으며, 조직구분과 모든 성격강점이 유의한 부적관계(r=-.18 -.29) 를 보여 서비스센터에 근무하는 종업원들의 성격강점이 전시장 종업원들에 비해 유의하게 낮은 것으로 나타났다. 본 연구 대상의 서비 스접전 종업원들의 성격강점을 살펴보면, 대 인관계 강점 $(\mathrm{M}=3.62, \mathrm{SD}=.40)$ 과 초월적 강점 $(\mathrm{M}=3.62, \mathrm{SD}=.33)$ 의 평균이 다른 성격강점에 비해 높았으며, 정서노동 내면행위 $(\mathrm{M}=3.62$, $\mathrm{SD}=.61)$ 를 표면행위 $(\mathrm{M}=3.10, \mathrm{SD}=.75)$ 보다 많 이 사용하는 것으로 나타났다. 정서노동의 내 면행위는 6 개의 성격강점에 모두 유의한 정적 관계(r=.43 .53)를 가졌으며, 표면행위는 초월 강점을 제외한 5 개의 성격강점과 유의한 부적 관계( $r=.-20 \sim-24)$ 를 가졌다. 행복은 6 개의 성 격강점 $(r=.45 \sim .60, p<.001)$ 및 내면행위 $(r=.48$, $p<.001)$ 와 유의한 정적관계를 보였으며, 부정 정서와는 유의한 부적관계 $(r=.-21, \mathrm{p}<.05)$ 를 나 타냈다. 반면, 부정정서는 6개의 성격강점과 모두 유의하지 않았으며, 내면행위와는 유의 한 부적관계( $r=.-18, \mathrm{p}<.05)$ 를, 표면행위( $r=.-21$, $\mathrm{p}<.05)$ 에는 유의한 정적관계를 나타냈다. 성격 강점과 정서적 측면에서의 행복을 살펴보면, 긍정정서는 6개 성격강점 모두와 유의한 정적 관계 $(\mathrm{r}=.45 \sim .60)$ 를 가진 반면 부정정서는 정서 적 강점 $(\mathrm{r}=-.17, \mathrm{p}<.01)$ 과 초월적 강점 $(\mathrm{r}=-.15$, $\mathrm{p}<.01)$ 에서만 유의한 부적관계를 나타내 용감, 끈기, 활력, 진실성의 정서적 강점과 심미안, 감사, 낙관성, 유머감각, 영성의 초월적 강점 을 가졌을 때 정서노동 종업원들은 부정적 정 
서를 덜 경험하는 것으로 나타났다.

\section{대인관계 강점이 행복에 미치는 영향}

대인관계 강점이 행복에 미치는 영향에 대 한 주 효과를 검증하기 위해 연령, 학력, 조직 구분, 부정정서를 통제변인으로 투입한 후, 정 서노동의 수행방식을 2단계에서 투입하여 위 계적 회귀분석을 실시하였다. 표 3에서 보는 바와 같이, 통제변인에서는 부정정서는 긍정 정서에 유의한 부적영향 $(\beta=-.37, \mathrm{p}<.001)$ 을 미 쳐, 부정정서가 높으면 행복감이 낮은 것으로 나타났다. 1단계 통제변인 투입, 2단계 인지적 강점, 정서적 강점, 절제적 강점, 시민적 강점, 초월적 강점을 투입 후 마지막에 대인관계 강 점과 행복간의 관계를 살펴본 결과, 대인관 계 강점은 행복과 유의한 정적영향 $(\beta=-.41$, $\mathrm{p}<.01)$ 을 보여 가설 1-1과 가설 1-2는 모두 지 지되는 것으로 나타났다.
정서노동 수행방식과 행복 간의 관계에서 대 인관계 강점의 조절효과

정서노동이 행복에 미치는 영향과 이 둘 간 의 관계를 대인관계 강점이 조절하는지를 살 펴보기 위해, 먼저 1단계에 통제변인, 2 단계에 정서노동 수행방식, 3 단계에 대인관계 강점, 4 단계에 상호작용 항을 투입하여 결과를 살펴 보았다. 분석결과, 정서노동 수행방식이 행복 에 미치는 영향에 대한 가설 2에 대한 분석에 서는 표 4에 제시되어 있는 바와 같이 정서노 동의 내면행위만이 유의한 정적 영향 $(\beta=.37$, $\mathrm{p}<.001)$ 을 미치는 것으로 나타나 가설 2-1은 지지되었다.

대인관계 강점의 조절효과를 살펴보기 위해 서는 Frazier 등(2004)이 추천한 방법을 사용하 였다. 즉, 각 변인의 $\mathrm{z}$-점수를 사용하여 비표준 화 된 회귀계수를 이용하여 회귀식을 만들고, 상호작용 효과가 있는 각 변인이 평균에서 1

표 3. 대인관계 강점이 행복에 미치는 영향에 대한 위계적 회귀분석 결과

\begin{tabular}{|c|c|c|c|c|c|c|}
\hline \multirow{2}{*}{ 단계 } & \multirow{2}{*}{ 변수 } & \multicolumn{5}{|c|}{ 긍정정서 } \\
\hline & & $\beta$ & $\mathrm{t}$ & $\mathrm{R} 2$ & $\triangle \mathrm{R} 2$ & $\mathrm{~F}$ \\
\hline \multirow{4}{*}{1} & 연령 & -.13 & -1.48 & \multirow{4}{*}{.17} & & \multirow{4}{*}{$7.2 * * *$} \\
\hline & 학력 & .05 & .53 & & & \\
\hline & 조직구분 & -.09 & -1.04 & & & \\
\hline & 부정정서 & $-.37 * * *$ & -4.49 & & & \\
\hline \multirow{5}{*}{2} & 인지적 강점 & -.14 & -.90 & \multirow{5}{*}{.37} & \multirow{5}{*}{$.23 * * *$} & \multirow{5}{*}{$8.9^{* * *}$} \\
\hline & 정서적 강점 & .60 & .93 & & & \\
\hline & 절제적 강점 & .06 & .08 & & & \\
\hline & 시민적 강점 & -.13 & -.28 & & & \\
\hline & 초월적 강점 & .08 & .42 & & & \\
\hline 3 & 대인관계 강점 & $.41 * *$ & 3.22 & .42 & $.05^{* *}$ & $10.4 * *$ \\
\hline
\end{tabular}

표준화 계수임 $* p<.05, * * p<.01, * * * p<.001$ 
한국심리학회지: 산업 및 조직

표 4. 정서노동 수행방식이 행복에 미치는 영향에서의 대인관계 강점의 조절효과

\begin{tabular}{|c|c|c|c|c|c|c|}
\hline \multirow{2}{*}{ 단계 } & \multirow{2}{*}{ 변수 } & \multicolumn{5}{|c|}{ 긍정정서 } \\
\hline & & $\beta$ & $\mathrm{t}$ & $\mathrm{R} 2$ & $\triangle \mathrm{R} 2$ & $\mathrm{~F}$ \\
\hline \multirow{4}{*}{1} & 연령 & -.02 & -1.48 & \multirow{4}{*}{.17} & \multirow{4}{*}{.19} & \multirow{4}{*}{$7.2 * * *$} \\
\hline & 학력 & .03 & .53 & & & \\
\hline & 조직구분 & -.11 & -1.04 & & & \\
\hline & 부정정서 & $-.29 * * *$ & -4.49 & & & \\
\hline \multirow{2}{*}{2} & 정서노동 내면행위 & $.37 * * *$ & 4.98 & \multirow{2}{*}{.30} & \multirow{2}{*}{.15} & \multirow{2}{*}{$10.1 * * *$} \\
\hline & 정서노동 표면행위 & -.010 & -.15 & & & \\
\hline 3 & 대인관계 강점 & $.63 * * *$ & 6.14 & .47 & .16 & $16.7 * * *$ \\
\hline \multirow{2}{*}{4} & 대인관계강점x내면행위 & $.08 *$ & 2.14 & \multirow{2}{*}{.48} & \multirow{2}{*}{.02} & \multirow{2}{*}{$13.8 * * *$} \\
\hline & 대인관계강점x표면행위 & .03 & .63 & & & \\
\hline
\end{tabular}

비표준화 계수임, ${ }^{*} p<.05,{ }^{* *} p<.01, * * * p<.001$

표준편차 위의 값과 1 표준편차 아래 값을 대 입하여 y 값을 산출한 뒤 네 개의 점을 연결 하는 방식이다. 상호작용에 대한 분석결과는 표 4의 모형 4에 제시되어 있다. 분석결과, 대 인관계 강점은 정서노동 내면행위와 유의한 상호작용 $(\beta=-.08, \mathrm{p}<.01)$ 을 나타내 가설 3-1이 지지되었다.
이를 구체적으로 살펴보기 위해 상호작용 효과를 도식화한 것이 그림 1 에 제시되어 있 다. 상호작용 효과를 더욱 명확하게 살펴보기 위해 Aiken과 West(1991)가 제시한 단순기울기 검증(simple slope test)를 실시하였다. 구체적으 로 보면, 대인관계 강점이 높은 구성원의 경 우(+1 SD), 회귀계수의 기울기 $(\beta=-.50, \quad \beta<.01)$

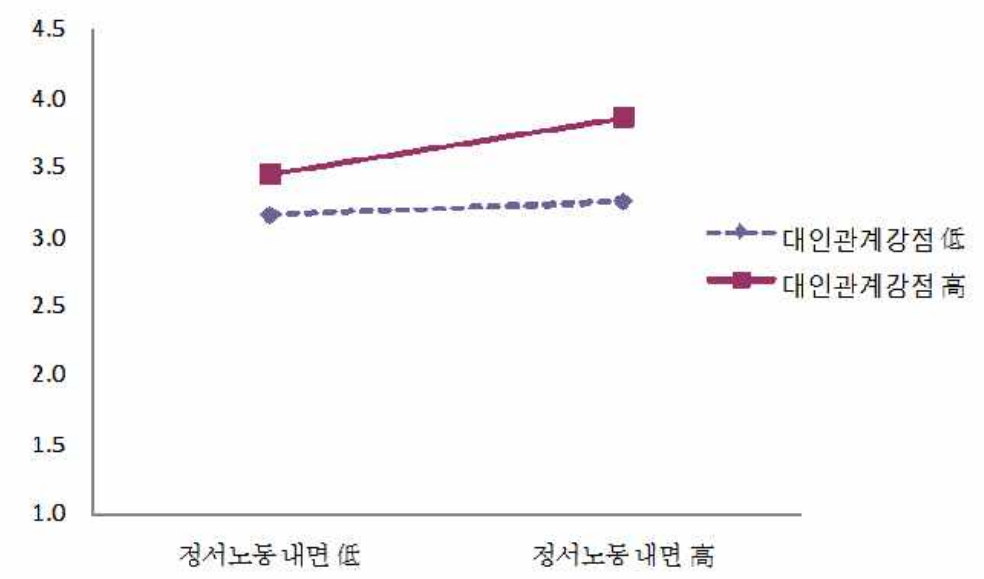

그림 1. 정서노동 내면행위가 행복 미치는 영향에서의 대인관계 강점의 조절효과 
가 통계적으로 유의하게 나타났다. 반면 대인 관계 강점이 낮은 경우(-1 SD), 회귀계수의 기 울기 $(\beta=-.05, \mathrm{p}=\mathrm{n} . \mathrm{s}$.$) 가 유의하지 않게 나타났$ 다. 따라서 대인관계 강점이 높은 경우 정서 노동 내면 행위가 행복에 미치는 정적 관계가 더욱 강한 것으로 나타났다. 즉, 대인관계 강 점이 높은 경우 내면행위를 많이 하는 사람은 그렇지 않은 사람에 비해 더욱 행복감을 느낀 다고 해석할 수 있다.

$$
\text { 논 의 }
$$

\section{주요 결과 및 시사점}

최근 들어 정서노동이 사회적 이슈로 더욱 부각되면서, 정서노동자들의 근무여건 개선 및 완화 방안에 대한 논의 또한 활발하게 이 루어지고 있다3). 본 연구에서는 개인의 어떠 한 특성이 이와 같은 정서노동의 어려움을 완 화시킬 수 있는지에 답하기 위해 최근 여러 학문분야에서 긍정적 효과를 발휘한다고 보고 되어 온 성격강점에 주목하여, 129 명의 수입 전자제품 접수원을 대상으로 대인관계 강점에 초점을 맞춰 크게 다음의 목적을 수행하고자 하였다. 본 연구에서는 다양한 학문 분야에서 성격강점에 대한 연구가 활발히 전개되고 있 음에도 불구하고 조직 장면에서 성격강점이 행복에 미치는 영향에 대한 실증적 연구가 부 족하다는 점에 주목하여 서비스 접점에서 근 무하고 있는 정서노동자들의 성격강점을 확인 해보고자 하였으며, 그 다음으로, 조직에서의 성격강점 특히 정서노동자들에게 유용하다 여

3) 서울시, 4개 기업과 감정노동자 인권향상 협약 체결, KBS, 2015년 10월 7일자 보도
겨지는 대인관계 강점이 행복에 유의한 영향 을 미치는지를 살펴보고자 하였다. 그리고 마 지막으로 본 연구에서는 정서노동자가 수행하 는 정서노동 수행방식이 행복에 미치는 영향 에 있어서 대인관계 강점이 어떠한 조절효과 를 나타내는지 확인하였다. 본 연구에서 나타 난 주요한 결과는 다음과 같다.

첫째, Peterson과 Seligman(2004)에 의해서 개 발된 24개 성격강점을 6개 성격강점(인지적 강점, 대인관계 강점, 정서적 관점, 절제적 강 점, 시민적 강점, 초월적 강점)으로 재분류하 여 위계적 회귀분석을 실시한 결과, 인구통계 학적 변인과 다른 성격강점을 모두 통제한 후 에 사랑, 친절, 사회지능으로 구성된 대인관계 강점은 긍정정서로 정의된 행복에 유의하게 정적 영향을 나타냈다. 특히, 이 분석에서 주 목할 점은 상관분석에서는 모든 성격강점이 행복과 유의한 정적관계를 보였으나 위계적 회귀분석 결과에서는 대인관계 강점을 제외한 5 개 강점은 모두 행복과 유의한 결과를 나타 내지 못한 것이다. 이는 기존의 성격강점과 행복에 대한 연구 결과와 맥을 같이 한다 할 수 있다. 즉. 성격강점은 그 정의의 특성상 개 인이 보유하고 있는 긍정적 특질이기 때문에, 기존의 여러 연구에서는 대상에 관계없이 대 부분의 성격강점은 행복과 유의한 정적 상관 을 가졌다(예: 임영진, 2010). 하지만 이와 동 시에 성격강점은 대상에 따라 성격강점과 행 복간의 관계 강도가 달라지는 특징이 있었다 (예: 김성숙, 2012; 김지영, 2011). 에를 들어, 유아교사들을 대상으로 한 김성숙(2012)의 연 구에서는 사회지능, 감사, 호기심이 다른 성격 강점에 비해 유의하게 행복과 강한 정적 상관 을 나타냈으며, 국내 대학생들을 대상으로 한 김지영(2011)의 연구에서는 낙관성, 끈기, 용감 
성이 심리적 안녕감과 강한 정적 상관을 나타 냈다.

이 결과들은 개인이 지니고 있는 각각의 성 격강점이 개인의 행복과 관련되나 동시에 어 떠한 대상이냐에 따라 더 중요한 성격강점이 존재함을 시사한다. 서비스 접점 정서노동자 를 대상으로 한 본 연구에서는 사람들과 대면 하고 상호작용하는 대인관계 강점이 행복과 가장 강한 관련성이 있는 것으로 확인되었다. 이는 정서노동자를 관리해야 하는 조직에서의 인적자원관리 측면의 실무적 시사점을 제공한 다. 즉, 조직에서 정서노동 관련된 종업원을 선발, 이동 및 교육을 실시할 때 대인관계 강 점을 발굴, 개발할 수 있도록 돕는다면 정서 노동자들의 행복과 안녕에 큰 도움을 줄 것이 라 기대된다.

이와 더불어, 본 연구의 결과는 성격강점 연구를 조직 장면으로 확장했다는 축면에서 학문적 의의를 갖는다. 긍정심리학이 소개된 이후 성격강점은 척도 개발 및 타당화(Peterson \& Seligman, 2004)를 비롯하여 개입 프로그램의 효과성 검증(이문희, 이영순, 2013)에 이르기까 지 다양한 학문 분야에서 주목을 받고 있다. 예를 들어, 임상 장면에서는 성격강점을 통한 치료 및 개선 프로그램을 통해 정신병리 개선 의 가능성을 검증(임영진, 2010)하고 있으며, 이외에도 상담, 교육, 스포츠 장면에서도 성격 강점을 적용해 약점의 보완이 아닌 강점의 개 발을 위한 실증적 증거들을 발견하고 있다(서 현아, 김미옥, 2013; 이현영, 김경원, 2010). 이 와 같이 성격강점 연구가 여러 영역에서 활발 히 전개되고 있음에도 불구하고 조직 장면에 서의 실증적 연구는 많이 이루어지지 못하였 다. 비록 성격강점을 활용한 조직 연구가 초 기단계에 있지만 향후에 더 많은 연구를 통해
구성원들이 강점 개발에 있어 많은 시사점을 제공해주리라 기대된다.

둘째, 본 연구에서는 기존의 정서노동 연 구에서 많은 연구자들이 주목하였던 정서노 동 수행방식(예: 노혜미 등, 2007; 박건우 등, 2014; 박선애, 이재창, 2014)에 초점을 맞춰 정 서노동의 표면행위와 내면행위가 행복에 미치 는 영향을 살펴보았다. 수입전자제품 전시장 과 서비스센터 접수원들을 대상으로 정서노동 수행방식이 행복에 미치는 영향을 분석한 결 과, 정서노동의 내면행동만이 행복에 유의한 정적 영향을 미치는 것으로 나타났다. 비록 정서노동의 표면행위는 행복과 부적 상관을 보이며 가설과 동일한 방향의 경향성을 나타 내긴 하였으나 유의한 결과를 보이지는 못하 였다. 정서노동 연구자들이 정서노동 수행방 식과 관련하여 표면행위는 조직과 정서노동자 들에게 부정적 결과를, 반대로 내면행위는 긍 정적 결과를 가져온다는 공통적으로 제안하고 있지만(예: 김문숙 등, 2014), 표면행위와 내면 행위가 항상 일관되게 상반된 결과를 나타내 며 이를 지지하고 있지는 않다(박춘신, 장재윤, 2012). 예를 들어, 박춘신과 장재윤(2012)의 연 구에서 표면행위는 정서적 고갈과 정적 관계 를, 내면행위는 정서적 고갈과 부적 관계를 보이며 상반된 결과를 보여주었다. 그러나 고 객지향성에 있어서는 표면행위는 고객지향성 과 아무런 관계가 없는 반면 내면행위는 고객 지향성과 유의한 정적 관계를 보여, 동일한 양상을 보이지 못하였다.

본 연구에서는 내면행위만이 행복과 유의한 정적 관계를 나타내고 표면행위는 유의한 관 계를 보이지 못하였는데, 최근에 이루어진 몇 몇 연구 결과를 통해 해석이 가능할 것으로 보인다. 박선애와 이재창(2014)의 연구에서는 
결과변인으로 직무탈진과 직무열의를 제안함 으로써 결과가 긍정변인이냐 부정변인이냐에 따라 정서노동 수행방식이 어떻게 달라지는지 를 검증하였다. 그 결과, 표면행위는 직무탈진 에 정적 영향을 주는 반면, 내면행위는 직무 열의에 정적 영향을 나타내 표면행위는 부정 적 변인에 강한 영향을 나타낸 반면 내면행위 는 긍정적 변인에 강한 영향을 나타냈다. 정 서노동 수행방식과 조직시민행동 간의 관계를 살펴본 공혜원, 김효선(2014)의 연구에서도 내 면행위는 조직시민행동에 유의한 정적 관계를 가진 것에 반해 표면행위는 아무런 관계를 갖 지 않아 본 연구의 결과와 동일한 양상을 나 타냈다.

이와 같은 결과는 앞서 이론적 배경에서 언 급한 Hackman과 Oldham(1975)의 직무특성 이 론의 원리로 해석이 가능하다 할 수 있다. 내 면행위는 Ashforh와 Humphrey(1993)가 제안한 또 다른 종류의 정서노동인 자연발생적 정서 (spontaneous and genuine emotion)와 다르게 정서 노동자가 규범적 정서와 일치하는 방향으로 자신의 내적 정서를 적극적으로 변화시키려고 노력하는 것이다. 정서노동을 행해야 하는 직 무에서 내면행위를 적극적으로 수행하는 사람 들은 내면행위를 통해 내적정서를 적극적으로 변화시켜 일에 대한 몰입감과 의미감을 증가 시켜 더 큰 만족감과 성취감을 느낄 수 있다. 따라서 조직에서는 이러한 원리를 적용하여 서비스 교육 시 자신의 감정과 고객의 응대에 대한 태도를 일치할 수 있는 내면행위의 중요 성을 강조하여 이것이 고객뿐만 아니라 정서 노동자의 행복에도 관련이 있음을 강조할 필 요가 있을 것이다.

본 연구는 정서노동 수행방식과 행복을 살 펴보았다는 점에 있어 학문적 의의가 있다.
정서노동 연구에서도 부정적 관점이 아닌 더 많은 긍정적 관점이 필요하다는 Humphrey 등 (2015)의 제안을 반영하듯 국내외 여러 연구 들도 직무열의(박선애, 이재창, 2014), 조직몰 입(노혜미 등, 2007), 동정심과 자긍심(이주일, 2008)등과 같은 긍정 변인과의 관계를 살펴보 고 있다. 하지만 여전히 부정변인에 비해 긍 정변인간의 관계를 다룬 연구는 많지 않은 것 이 사실이다. 따라서 향후 연구에서는 더 많 은 긍정적 변인과의 관계를 살펴봄으로써 정 서노동 수행방식의 결과변인이 긍정 변인인가 아니면 부정 변인인가에 따라 어떻게 관계가 변화하는지를 살펴보며 이와 관련된 메커니즘 을 상세히 밝힐 필요가 있을 것이다.

셋째, 본 연구에서는 정서노동 수행방식이 행복에 미치는 영향에서 서비스 접점 종업원 들에게 핵심적인 성격강점으로 나타난 대인관 계 강점이 유의한 조절효과를 나타내는지 살 펴보았다. 즉, 본 연구에서는 대인관계 강점은 정서노동의 내면행위의 긍정적 영향을 더욱 강하게, 그리고 정서노동의 표면행위의 부정 적 영향은 더욱 완화시킬 것으로 예상하였다. 그 결과, 대인관계 강점은 내면행위의 강화효 과만을 나타내 대인관계 강점을 가진 사람들 은 그렇지 않은 사람에 비해 정서노동의 내면 행위를 할 때 더욱 강하게 행복감을 느끼는 것으로 나타났다. 그렇다면 왜 대인관계 강점 이 높을 때 강화 효과를 내는 것일까? 본 연 구에서 사용한 대인관계 강점은 사랑, 친절성, 사회지능의 강점이 포함된 개념으로, '자애 (humanity)'와 관련된 강점(Peterson \& Seligman, 2004)이었다. 이는 다른 사람을 보살피고 이해 하며 그들과 따뜻하고 친밀한 관계를 형성하 도록 돕는 강점들로 정의된다. 정서노동은 그 업무의 특성상 대인관계 속에서 이루어지는 
행위이다. 정서노동을 통한 행복이란 대인관 계를 잘 수행하면서 얻어질 수 있는 결과물이 기 때문에, 업무 자체가 이러한 강점을 발휘 하고 활용할 수 있는 기회가 되어 강점을 발 휘하는 행복한 삶을 경험하게 된다(Seligman, 2002). 대인관계 강점이 높은 사람이 내면행위 를 하였을 때 그 진심과 능숙한 대인관계 기 술이 고객 및 상사로부터의 긍정적인 피드백 과 높은 성과를 달성할 확률을 높일 수 있고 또 이것이 만족감을 높일 수 있다. 즉 Emmons 와 McCullough(2003)가 밝힌 바와 같이, 이러한 상호교류적인 관계(reciprocal relationships)는 더 욱 만족감을 높일 수 있는 기회가 될 수 있다. 점차 직업불안정성이 높아지고, 직업이동이 많아지면서 직업의 세계는 평생직장에서 평생 직업으로 변화하고 있다(장원섭, 2007). 이러한 상황에서 자신의 직무, 즉 정서노동 상황에서 더 만족감을 강화시킬 수 있는 요인의 발견은 인적자원 관리 차원에서 중요할 수 있다.

정서노동 연구에서 정서노동으로 인한 부정 적 측면을 완화시킬 수 있는 조절변인을 발견 하는 것은 핵심적인 연구 주제일 수 있다. 그 러한 측면에서 대인관계 강점이 정서노동의 표면행위와 행복간의 부적 관계를 약화시키지 않음이 밝혀진 것은 대인관계 강점의 효용성 의 제한점이라 할 수 있다. 그렇다면, 왜 정서 노동의 표면행위의 부정적 영향을 완화시켜주 지 못했는가? 이에 대해 몇 가지 해석이 가능 할 것으로 보인다. 우선 이는 아마도 정서노 동 수행방식과 행복 간의 결과에서도 나타났 듯이 정서노동 수행방식의 결과변인이 긍정변 인인 행복이기 때문이라 여겨진다. 즉, 표면행 위는 행복이라는 긍정변인보다는 부정변인에 서 더욱 깊은 관계가 있기 때문에 조절변인의 역할이 충분히 나타나지 않았을 가능성이 있
다. 또 다른 이유로는 대인관계 강점 역시 긍 정변인으로 긍정적 측면을 더욱 강화하는 역 할을 하지 부정적 측면을 약화시키지는 못하 는 것으로 해석할 수 있다. Herzberg(Herzberg, Mauser, \& Synderman, 1959)가 제안한 동기-위 생이론(motivation-hygiene theory)과 같이 불만족 을 충족시키는 변인과 행복을 증가시키는 변 인은 따로 존재할 가능성이 있다. 비록 본 연 구의 자료가 동일한 시점에 측정하여 긍정변 인들 간의 상관이 서로 높을 수 있다는 가능 성 또한 존재하지만, 성격강점은 그 정의상으 로도 그것이 인식되고 발휘되었을 때 행복감 을 느끼는 것이기 때문에 내면행동으로 인한 행복감을 대인관계 강점을 통해 더욱 증가시 키는 역할만 한다고 해석할 수 있을 것이다.

이러한 결과들을 바탕으로, 본 연구는 종합 적으로 크게 두 가지의 이론적, 시사점을 제 공한다. 본 연구에서는 정서노동을 수행방식 이 직무태도에 미치는 영향에 대한 기존 연구 결과에서 더 나아가, 개인 특성 변인에 따라 서 그 영향력이 달라질 수 있음을 뒷받침 하 는 하나의 증거를 마련했다 할 수 있다. 기존 의 정서노동의 조절변인에 대한 몇몇 연구들 은 조직의 지원, 직무 특성과 같은 조직의 맥 락적 특징에 초점을 맞추어, 정서노동 환경에 시사점을 제공해주어 왔다(김영조, 한주희, 2008; 신강현 등, 2006). 하지만 이에 더 나아 가, 기업의 역량이 적합한 인재(right people) 확보에 있다 해도 과언이 아니다(Cross \& Pruksak, 2002). 서비스 업종에서 개인이 서비 스 질이 조직성과에 핵심적인 영향을 미치는 사실을 고려해본다면, 직무에 맞는 개인특성 및 고유한 강점의 발견은 조직현장 관점에서 중요한 일임에 틀림없다. 이는 향후 연구에서 는 대인관계 강점 이외에도 정서노동에서 중 
요한 역할을 하는 더 많은 개인특성들을 발견 할 필요가 있음을 시사하고 있다.

다음으로, 본 연구는 조직 장면에서 성격강 점의 효과에 대한 실증적 연구로서, 인사 선 발과 교육 프로그램 등을 통해 대인관계 강점 을 활용할 필요성이 있음을 시사하고 있다. 서비스 업체의 종업원은 물론이며 제조업체의 영업직원, 내부 고객과의 접촉 기회가 잦은 중간관리자 등 감정표현이 직무의 일부분을 이루는 직업은 여러 산업에 걸쳐 폭넓게 분포 되어 있으며(Rafaeli \& Sutton, 1989; Wharton \& Erickson, 1993) 조직에서 이루어지는 대인관계 의 일정부분은 정서노동임에 분명하다(박건우, 등 2014). 또한 일부 조직에서는 정서노동이 피할 수 없는 주요 핵심 직무이다. 이러한 이 유로, 대인관계 강점은 서비스업종을 비롯한 일반 조직에도 유용성을 제공하기라 여겨지며, 정서노동의 효과적인 수행을 위해서는 대인관 계 강점을 강조한 직원 선발과 개발 및 교육 이 필요하다고 할 수 있다. 따라서 본 연구의 결과는 어떤 분야에 대한 투자가 정서노동의 질을 향상시켜 조직 효과성을 증대시키는데 실효성을 가져올지에 대한 하나의 근거 자료 로 활용될 수 있다. 즉, 대부분의 조직에서 이 미 선발한 직원에 대해서는 교육과 훈련을 통 해 성과를 높이는 것이 주요 과업인데, 정서 노동을 수행하는 직원들에게는 대인관계 강점 을 높이기 위한 교육 및 훈련에 초점을 두도 록 하는 것이 서비스 조직의 성과 증진에 효 과적일 수 있다는 점을 시사하고 있다.

\section{제한점 및 향후 연구 방향}

본 연구가 대인관계 강점과 행복, 그리고 정서노동과 직무태도에 대인관계 강점의 핵심
적인 역할을 검증함으로써 학문적, 실무적 의 의를 제공했음에도 불구하고, 성격강점을 조 직에 적용하는 초기 연구라는 점에 있어 여러 가지 측면에서 보완되어야 할 필요가 있다. 첫째, 조직에 적용할 수 있는 성격강점 척 도의 보완에 대한 것이다. 본 연구에서는 연구방법에서 설명한 것과 같이, Peterson과 Seligman(2004)이 개발한 240 문항의 VIA-IS를 한 국화한 권석만(2009)의 척도를 사용하여, 240 문항 가운데 각 성격강점 당 3 문항씩을 선별 하여 총 72 문항을 측정하여 연구에 사용하였 다. 비록 이것이 조직에서의 설문응답의 효율 성을 높이고 조직에서 허용한 설문시간 제약 사항을 극복하기 위한 방법이었음에도 불구하 고, 축약본을 사용하였다는 점에 있어 제한점 이 존재한다. 즉, 본 연구에서는 24 개의 각 성 격강점에 해당되는 문항이 3문항으로 구성되 어 있어, 24 개의 각 요인에 대한 타당도를 확 보하기에 적은 수의 문항으로 측정되었다. 본 연구에서는 6개 요인의 성격강점의 대분류에 의한 분석이 이루어져 조직 장면에서 성격강 점의 영향을 살펴보긴 하였으나 24개로 구분 되어 있지 못해 대인관계 강점이 효과가 있다 고 해도 그것을 이루고 있는 사랑, 친절, 사회 지능의 각 세부 요인이 의미하는 바에 대해서 는 구체적으로 살펴보지 못하였다. 따라서 향 후에 조직에서 성격강점의 효과를 더욱 명확 히 검증하기 위해서는 한국 조직 맥락에 적합 한 성격강점 척도에 대한 개발이 필요하다 할 수 있다. 최근 해외의 성격강점연구소니에서는 해외의 여러 나라의 조직 장면에서 타당화한 120 문항의 척도를 개발하여 보급에 힘쓰고 있 다. 따라서 국내에서 성격강점이 조직에서 더 욱 적용되기 위해서는 조직에서의 제약된 조

4) https://www.viacharacter.org 
건을 고려한 120 문항의 척도에 대한 타당도와 신뢰도를 확보한 뒤 더 많은 연구가 이루어질 필요가 있다.

둘째, 조직에서의 성격강점과 행복 간의 관 계를 더욱 명확히 살펴보기 위해서는 행복변 인에 대한 고려가 이루어져야 할 것으로 보인 다. 본 연구에서는 정서노동을 수행하는 종업 원을 대상으로 하였다는 점에 주목하여 정서 노동 상황과 더욱 연계가 있다고 여겨지는 정 서적 측면에서의 행복에 초점을 맞췄다. 그러 나 행복은 그 정의 자체가 다양한 측면을 포 함하고 있어 단순하게 하나로 정의하거나 측 정하기 쉽지 않기 때문에 연구자들마다 행복 의 정의와 측정을 다소 다르게 하고 있다 (Fisher, 2010). 심리학을 중심으로 연구자들은 행복을 대개 쾌락주의적 안녕감을 바탕으로 한 주관적 안녕감(subjective well-being)과 자 아실현적 안녕감을 반영항 심리적 안녕감 (psychological well-being)으로 구분하여 연구 하고 있으나(박선영, 2013), 그 외에도 역량 (competence), 열망(aspiration), 자율성(autonomy), 만족감(satisfaction) 등이 행복으로 간주하여 연 구하기도 한다(Daniels, 2000; Diener, 2000). 더 욱이 Fisher(2010)에 따르면, 조직의 행복에서는 “행복”이라는 단어를 직접적으로 사용하기 보 다는 긍정정서, 직무만족, 조직몰입 등을 행복 과 동일한 것으로 간주해 연구했기 때문에 행 복에 대한 명확한 정의나 구성개념에 대한 논 의는 많이 이루어지지 못한 것이 사실이다. 따라서 향후 연구에서는 조직의 대상과 맥락 에 따라 어떠한 행복변인 사용되어야 하며, 이것이 의미하는 바에 대해 더 많은 논의가 필요할 것으로 보인다.

셋째, 본 연구에서는 정서노동을 하는 대상 자를 하나의 회사의 수입전자제품 접수원들로
한정하여 연구모형을 검증해보았다. 비록 20 여개의 전시장과 서비스센터의 접수원을 대상 으로 설문을 실시했음에도 불구하고, 하나의 회사에서 설문이 이루어졌다는 점과 접수원 대부분이 여성이라는 점으로 인해 일반화에 제한이 있을 수 있다. 따라서 향후 연구에서 는 성별, 연령 등의 다양한 인구통계학적 변 인과 정서노동자가 속한 산업별 특징을 고려 하여 대인관계의 강점이 정서노동 장면에서의 어떠한 영향력을 미치는지 재확인해볼 필요가 있으며, 이를 통한 일반화 가능성을 높일 필 요성이 있다.

넷째, 본 연구에서 대인관계 강점의 조절효 과를 살펴보기 위해 본 연구에서는 기존에 정 서노동의 조절변인이라고 알려진 조절변인들 을 통제하지 않은 채 대인관계 강점의 조절효 과를 살펴보았다. 대인관계 강점은 기존의 $\mathrm{Big}$ 5 의 호의성, 외향성과 높은 상관을 가지고 있 을 가능성이 있다. 따라서 향후 연구에서는 이러한 기존의 개인특성변인과 대인관계 강점 이 차별적으로 구분되는 개념인지에 대한 정 밀한 분석과 또한 유사한 개인특성 변인을 통 제한 후에도 대인관계 강점이 조절효과를 나 타내는지 검토할 필요가 있다.

다섯째, 본 연구에서는 대인관계 강점이 정 서노동의 내면행위와 행복간의 관계에서만 유 의한 조절효과를 나타내고 정서노동의 표면행 위와 행복간의 관계에서는 조절효과를 나타내 지 못하였다. 하지만. 정서노동의 경우, 직무 의 특성상 내면행위보다는 외현적으로 서비스 를 제공해야 하는 표면행위를 더 많이 할 가 능성이 높다. 따라서 이러한 경우에는 표면행 위의 부정적 영향을 완화시킬 수 있는 개인특 성 변인을 발견하는 것이 의미가 있을 수 있 다. 따라서 향후 연구에서는 정서노동의 부정 
적 영향을 약화시킬 수 있는 다양한 조절효과 를 발견하는 것 또한 필요할 것으로 보인다.

여섯째, 본 연구에서는 대인관계 강점의 효 용성을 살펴보는데 있어 대인관계를 보유한 사람의 행복이 어떠한지를 살펴보았다. 하지 만 본 연구가 이루어진 장면이 조직이라는 점 을 고려한다면 대인관계 강점과 행복, 그리고 성과 간의 관계를 살펴볼 필요가 있다. 조직 은 성과창출을 목적으로 이루어진 것이기 때 문에 개인의 행복이 과연 성과와 관련성이 있 는지를 살펴보는 것이 중요할 수 있다. 따라 서 향후 연구에서는 성격강점과 행복, 그리고 성과가 서로 연계되어 이루어지는지, 또는 성 격강점이 행복과 성과에 듀얼로 영향을 미치 는 등 다양한 모델을 통해 성과와의 관련성을 살펴볼 필요가 있다.

마지막으로 본 연구는 종단연구 설계가 아 닌 일회성 설문에 의해 보고된 결과를 바탕 으로 수행되었다. 향후 연구에서는 시간차를 바탕으로 한 종단설계를 통해 동일방법편의 (common method bias)에 의한 제한점을 보완하 여 긍정적 변인들의 상관으로 인한 결과를 보 완해줄 수 있을 것으로 기대된다. 특히 이것 은 과연 정서노동의 내면행위가 행복을 이끄 는가 아니면 행복이 정서노동의 내면행위를 이끄는가에 대한 물음에 답을 제공해 줄 것 이라 여겨진다. 예를 들어, 차정주와 이효림 (2015)의 연구에서는 현직 유아교사를 대상으 로 정서노동의 내면행위가 행복에 정적 영향 을 미침을 보여줌으로써 전자를 지지하고 있 으며, 반대로 박건우, 등(2014)의 연구에서는 국내 기업 종사자 435명을 대상으로 긍정정서 가 상사에 대한 정서노동 내면행위에 유의한 정적 영향이 있음을 보임으로써 후자의 가설 을 지지하였다. 향후 연구에서는 종단적 설계
를 통한 잠재성장모형 검증 등을 통해 정서노 동과 행복 간의 관계에 대한 인과 관계를 직 접적으로 비교, 검증할 필요가 있다.

\section{결론}

본 연구에서는 최근에 국내에서 사회적 문 제로 제기되고 있는 정서노동자의 인권문제를 긍정심리학적 관점을 접목하여 정서노동의 행 복을 다뤄보고자 하였다. 본 연구에서는 대인 관계 강점이 정서노동상황에서 행복에 긍정적 영향을 미치며 또한 정서노동의 내면행위를 통한 행복 간의 관계를 더욱 강화하는 것으로 나타났다. 성격강점의 접근은 문제 중심적 관 점에서 장점과 강점 중심의 긍정적 관점으로 전환의 대표적인 변인이라 할 수 있다. 앞으 로 많은 긍정적 접근의 발견을 통해 학문적으 로 뿐만 아니라 실무적으로 조직 구성원의 장 점을 살려 그들의 행복뿐만 아니라 성과 창출 에도 기여할 필요가 있을 것이다.

\section{참고문헌}

공혜원, 김효선 (2014). 감정조절전략이 조직시 민행동에 미치는 차별적 효과: 직무소진 의 매개효과를 중심으로. 조직과 인사관 리, 38(3), 1 31.

권석만 (2008). 긍정 심리학: 행복의 과학적 탐 구. 서울: 학지사

권석만 (2009). 서울대학교 리더십 향상 프로그 램의 운영을 위한 성격 강점 검사의 개발. 연구결과보고서.

권혁기, 박봉규 (2011). 서비스종사원 감정노동 의 표면행위와 내면행위가 감정부조화 및 
직무태도에 미치는 영향. 인적자원관리연 구, 18(1), 311-325.

김광수 (2002). 용서 프로그램이 대인관계 상

처경험자의 자존감, 불안, 분노에 미치는 영향. 청소년상담연구, 10(1), 165-191.

김광은, 윤유경, 권석만, 하승수 (2010). 긍정심 리학적 관점에서 본 사관생도의 성격적 강점과 행복 및 생활적응과의 관계. 한국 심리학회지: 상담 및 심리치료, 22(1), 233248.

김문숙, 김예실, 이순묵 (2014). 정서노동과 직무관련 변수들 간 관계: 메타분석 (Meta-Analysis), 한국심리학회지: 산업 및 조 직, 27(4), 683-717.

김성숙 (2012). 예비유아교사가 인식한 스트레 스 대처 방식 및 자아탄력성이 행복감에 미치는 영향. 열린유아교육연구, 17(3), 6583.

김영조, 한주희 (2008). 서비스 직원의 감정노 동 수행과 직무소진의 관계에 관한 연구. 인사관리연구, 32(3), 95-128.

김원형, 신강현, 허창구, 이종현 (2007). 정서노 동과 직무탈진: 자율성과 사회적 지지의 조절효과. 한국심리학회지: 건강, 12(4), 905-921.

김지영 (2011). 성격강점이 긍정적 정신건강에

미치는 영향. 서울대학교 박사학위논문.

김지영 (2014). 대학생의 성격강점 및 덕성과

성격장애와의 관계. 청소년학연구, 21(11), 75-99.

김지영, 권석만 (2013). 성격강점의 인식과 활 용이 정신건강에 미치는 효과. 한국심리학 회지: 임상, 32(4), 783-802.

김현정, 고영건 (2014). 성격강점 및 덕목 그 리고 행복 간 관계에서 학교적응의 매개
효과. 한국심리학회지: 학교, 11(1), 317334.

노지혜, 이민규 (2011). 나는 왜 감사해야 하는 가?: 스트레스 상황에서 감사가 안녕감에 미치는 영향. 한국심리학회지: 임상, 30(1), 159-183.

노혜미, 유태용, 신강현 (2007). 정서지능과 정 서노동 전략이 직무관련 태도에 미치는 영향: 개인적 성취감의 매개효과. 한국심 리학회지: 산업 및 조직, 20(4), 529-550.

박건우, 김명소, 한영석 (2014). 상사에 대한 정서노동의 예측변인 탐색 및 직무소진과 의 관계모형 검증. 한국심리학회지: 산업 및 조직, 27(1), 267-290.

박미진 (2007). 여성 노인의 스트레스와 우울 의 관계에서 강점과 사회적 지지의 완충 효과. 한국심리학회지: 여성, 12(2), 197211.

박선애, 이재창 (2014). 정서노동 전략이 직무 탈진 및 직무열의에 미치는 영향: 긍정심 리자본의 조절효과를 중심으로. 한국심리 학회지: 산업 및 조직, 27(4), 781-804.

박선영 (2013). 삶의 의미와 심리적 건강의 관 계: 다차원적 삶의 의미 척도와 의미감 증 진 프로그램 개발. 서울대학교 박사학위 논문.

박지연, 손영화 (2014). 일과 생활의 조화와 상 사-부하 관계가 조직몰입에 미치는 영향 직장에서의 행복을 매개변인으로. 한국심 리학회지: 산업 및 조직, 27(4), 781-804.

박춘신, 장재윤 (2012). 방문형 학습지 교사의 정서노동, 정서적 고갈, 이직의도 및 고객 지향성 간의 관계. 한국심리학회지: 산업 및 조직, 25(4), 775-799.

백승근, 신강현, 이종현, 허창구 (2014). 감정노 
박선희 · 이지영 / 정서노동 상황에서 서비스 접점 종업원들의 대인관계 강점이 행복에 미치는 영향

동, 피할 수 없을 때 누가 즐길 수 있는 가: 자기감시의 조절효과를 중심으로. 한 국심리학회지: 산업 및 조직, 27(4), 719745.

서현아, 김미옥 (2013). 유아교사의 성격 강점 이 심리적 안녕감과 직무만족도에 미치는 영향. 유아교육학논집, 17(1), 435-453.

신강현, 이 랑, 허창구, 김재연 (2006). 정서노 동 예측시 성격 5요인과 직무환경변수의 역할: 미국 호텔업 종사자를 대상으로. 한 국심리학회지: 산업 및 조직, 19(1), 105124.

신강현, 한영석, 김완석, 김원형 (2008). 정서노 동과 직무탈진 및 직무열의 관계: 정서지 능의 조절효과. 한국심리학회지: 산업 및 조직, 21(3), 475-491.

유정희 (2010). 방송인의 감정노동과 직무스트 레스가 심리적 안녕감과 소진에 미치는 영향. 심리행동연구, 2, 97-114.

이 랑, 김완석, 신강현 (2006). 직무탈진과 직 무열의의 요구-자원 모델에서 정서노동전 략의 역할-콜센타 상담원을 대상으로. 한국심리학회지: 산업 및 조직, 19(4), 573596.

이문희, 이영순 (2013). 성격 강점에 기반한 행 복증진 프로그램이 고등학생의 주관적 안 녕감, 탄력성 및 대인관계에 미치는 효과. 한국심리학회지: 상담 및 심리치료, 25 , 813-831.

이주일 (2008). 행복, 동정심 및 자긍심에 대한 정서노동 유발상황과 정적 정서노동의 심 리적 효과. 한국심리학회지: 산업 및 조직, 21(4), 769-797.

이현영, 김경원 (2010). VIA 분류체계에 근거한 규칙적 운동참여자의 지각된 성격 강점.
한국스포츠심리학회지, 21, 153-165.

이현희, 김은정, 이민규 (2003). 한국판 정적 정서 및 부적 정서 척도의 타당화 연구 한국심리학회지: 임상, 22, 935-946.

이형양, 이완정 (2012). 보육교사의 성격강점 상위 덕목이 생활 스트레스 및 직무스트 레스에 미치는 영향. 한국가정관리학회 추 계학술대회, 385 .

임영진 (2010). 성격강점과 긍정심리치료가 행복 에 미치는 영향. 서울대학교 대학원 박사 학위논문.

임영진 (2012). 주요우울장애 대학생을 대상으 로 한 긍정심리치료의 효과. 한국심리학회 지: 임상, 31(3), 679-692.

장원섭 (2007). 맥락 중심의 평생 진로교육 제 안. 진로교육연구, 20(2), 1-13.

정일진, 정재희, 김소영, 김윤나, 김대선 (2014). 청소년의 강점, 성격과 삶의 만족도의 관 계. 한국심리학회지: 학교, 11(3), 563-583.

차정주, 이효림 (2015). 유아교사의 소진과 정 서노동이 행복감에 미치는 영향. 열린유아 교육연구, 20(2), 375-393.

한주원 (2005). 개인성격과 감정노동 스트레스 가 직무만족에 미치는 영향. 비서학 논총, 14(1), 145-167.

한진환 (2012). 감정노동과 조직시민행동간 조직지원의 조절효과. 인적자원관리연구, 19(2), 83-101.

황재선, 신강현, 허창구, 김동근 (2010). 직무 요구와 자원이 정서노동에 미치는 영향: 스트레스 대처방식의 매개효과를 중심으 로. 한국심리학회지: 산업 및 조직, 23(3), 503-523.

황해익, 탁정화 (2015). 보육교사의 성격강점 에 대한 교육 요구도 분석. 유아교육연 
구, 35(2), 411-438.

Abraham, R. (1998). Emotional dissonance in

organizations: A conceptualization of consequences, mediators and moderators,

Leadership \& Organization Development Jaurnal, 193), 1-17.

Aiken, L. S., \& West, S. G. (1991). Multiple Regression: Testing and Interpreting Interactions, London: Sage.

Allport, G. W. (1955). Beconing. New Haven: Yale University Press.

Ashforth, B. E., \& Humphrey, R. H. (1993). Emotional labor in service roles: The influence of identity. Academy of Management Review, 18(1), 88-115.

Bono, J. E., \& Vey, M. A. (2007). Personality and emotional performance: Extraversion, neuroticism, and self-monitoring. Journal of Ccaupational Health Psychdogy, 12(2), 177-192.

Bowen, D. E,. Schneider, B. (1988). Services Marketing And Management: Implications For Organizational Behavior, In Staw, B. M., \& Cummings, L. L. (Eds). Research in Organizational Behavior, 10, Greenwich, CT: JAI Press.

Brotheridge, C. M., \& Grandey, A. A. (2002). Emotional labor and burnout: Comparing two perspectives of "People Work". Journal of Vocational Behavior, 60(1), 17-39.

Brotheridge, C. M., \& Lee, R. T. (2003). Development and validation of the emotional labor scale. Journal of Ocaupational and Organizational Psychdogy, 76(3), 365-379.

Brown, S. W., Gummesson, E., Edvardsson, B., \& Gustavsson, B. (1991). Service Quality:
Multidisaplinary and multinational perspectives. New York: Lexington Books.

Chan, D. W. (2009). The hierarchy of strengths: Their relationships with subjective well-being among Chinese teachers in Hong Kong. Teadhing and Teacher Education, 25(6), 867-875.

Côté, S. \& Morgan, L. M. (2002). A longitudinal analysis of the association between emotion regulation, job satisfaction, and intentions to quit. Jaurnal of Organizational Behavior. 23(8), 947-962.

Cross, R. \& Pruksak, L. (2002). The people that make organizations stop-or go. Harvard Business Review, 806), 104-112.

Daniels, K. (2000). Measures of five aspects of affective well-being at work. Human Relations, 53(2), 275-294.

Dawis, R. T., \& Lofquist, L. H. (1984). A Psychological Theory of Work Adjustment. Minneapolis: University of Minnesota Press.

Diefendorff, J. M., Croyle, M. H., \& Grosserand, R. H. (2005). The dimensionality and antecedents of emotional labor strategies. Jaurnal of Vocational Behavior, 66(2), 339-357.

Diener, E. (2001). Subjective well-being. Paper presented at the annual meeting of the Society for Personality and Social Psychology.

Diener, E., \& Lucas, R. E. (1999). Personality and Subjective Well-Being, In Kahneman, D., Diener, E., Lucas, R. E., \& Schwarz, N. (Eds). Well-being: Foundations of hedonic Psychology. (pp. 213-229), New York: The Rusself Sage Foundation.

Emmons, R. A. \& McCullough M. E. (2003). Counting blessings versus burdens: An 
experimental investigations of gratitude and subjective well-being in daily life, Jaurnal of Personality and Social Psychdogy, 84(2), 377-389.

Fisher, C. D. (2010). Happiness at work. International Journal of Management Reviews, 12(4), 384-412.

Frazier, P. A., Tix, A. P., \& Barron, K. E. (2004). Testing moderator and mediator effects in counseling psychology research. Jaurnal of Caunsding Psychdogy, 51(1), 115-134.

Fromm, E. (1947). Man for himself. New York: Holt, Rinehart \& Winston.

Gabriel, A. S., Daniels, M. A., Diefendorff, J. M., \& Greguras, G. J. (2015). Emotional labor actors: A latent profile analysis of emotional labor strategies. Journal of Applied Psychdogy, 1003), 863-879.

Gillham, J., Adams-Deutsch, Z., Werner, J., Reivich, K., Coulter-Heindl, V., Linkins, M., Winder, B., Peterson, C,. Park, N., Abenavoli, R., Contero, A., \& Seligman, M. E. P. (2011). Character strengths predict subjective well-being during adolescence. The jaurnal of Positive Psychology, Q1), 31-44.

Grandey, A. A. (2000). Emotional regulation in the workplace: A new way to conceptualize emotional labor. Journal of Crapational Health Psychdogy, 5(1), 95-110.

Grandey, A. A. (2003). When the show must go on: Surface acting and deep acting as determinants of emotional exhaustion and peer-rated service delivery. Academy of Management Jaurnal, 46(1), 86-96.

Ghobadian, A., Speller, S., \& Jones, M. (1994). Service Quality: concepts and models.
International Jaurnal of Quality \& Reliability Management, 11(9), 43-66.

Gross, J., \& Levenson, R. (1997). Hiding feelings: The acute effects of inhibiting negative and positive emotions. Journal of Abnormal Psychdogy, 1061), 95-103.

Güsewell A., Ruch W. (2012). Are emotional strengths emotional? Character strengths and disposition to positive emotions. Applied Psychdogy of Health and Well-Being, 4(2), 218-239.

Hackman, J. R. \& Oldham, G. R. (1975). Development of the Job Diagnostic Survey. Jaurnal of Applied Psychology, 602), 159-170.

Harzer C., \& Ruch, W. (2012). When the job is a calling: the role of applying one's signature strengths at work. The Jaurnal of Positive Psychology, 75), 362-371.

Harzer C., \& Ruch, W. (2013). The application of signature character strengths and positive experiences at work. Journal of Happiness Study, 14(3), 965-983.

Harzer, C., \& Ruch, W. (2015). The relationships of character strengths with coping, workrelated stress, and job satisfaction. Frontiers in psychology, 6, 165.

Herzberg. F., Mausner, B. \& Snyderman, B. (1959). The Motivation to Work. N.Y.: John Wiley \& Sons.

Hochschild, A. (1979). Emotion Work, Feeling Rules, and Social Structure. The American Journal of Socidogy, 85(3), 551-575.

Hochschild, A. (1983). The Managed Heart: Commerailization of Human Feeling, Berkeley: University of California Press. 
Hülsheger, U. R., Schewe, A. F. (2011). On the costs and benefits of emotional labor: A meta-analysis of three decades of research. Jaurnal of Ocaupational Health Psychdogy, 16(3), 361-389

Humphrey, R. H., Ashforth, B. E. \& Diefendorff, J. M. (2015). The bright side of emotional labor. Jaurnal of Organizational Behavior, 366), 749-769.

Johnson, H. M., \& Spector, P. E. (2007). Service With a Smile: Do Emotional Intelligence, Gender, and Autonomy Moderate the Emotional Labor Process? Jaurnal of Occupational Health Psychdogy, 12(4), 319-333.

Judge, T. A., Woolf, E. F., \& Hurst, C. (2009). Is emotional labor more difficult for some than for others? a multilevel experiencesampling study. Personnel Psychology, 62(1), 57-88.

Kammeyer-Mueller, J. D., Rubenstein, A. L., Long, D. M., Odio, M. A., Buckman, B. R. Zhang, Y., \& Halvorsen-Ganepola, M. D. K. (2013). A Meta-Analytic Structural Model of Dispositonal Affectivity and Emotional Labor. Personnel Psychdogy, 60(1), 47-90.

Kiffin-Petersen, S. A., Jordan, C. L., \& Soutar, G. N. (2011). The big five, emotional exhaustion and citizenship behaviors in service settings: The mediating role of emotional labor. Personality and Individual Differences, 50(1), 43-48.

Kruml, S. M., \& Geddes, D. (2000). Exploring the dimensions of emotional labor: The heart of Hochschild's work. Management Communication Quarterly, 14(1), 8-49.
Littman-Ovadia, H., \& Steger, M. (2010) Character strengths and well-being among volunteers and employees: Toward an integrative model. The Journal of Positive Psychdogy, 5(6), 419-430.

Lewig, K. A., \& Dollard, M. F. (2003). Emotional dissonance, emotional exhaustion, and jog satisfaction in call center jobers. European Jairnal of Job and Oganizational Psydhogy, 12(4), 366-392.

Lewis, B. R. (1989). Quality in the Service Sector: A Review, International Jaurnal of Bank Marketing. 7(5), 4-12.

Maslow, A. H. (1968). Toward a prychdogy of being. New York: John Wiley \& Sons.

McGrath, R. E. (2015). Character strengths in 75 nations: An update, The jaurnal of Positive Psychdogy, 101), 41-52.

Morris, J. A. \& Feldman, D. C. (1997). Managing emotions in the workplace. Journal of Managerial Issues, QX3), 257-274.

Mount, M. K., Barrick, M. R., Scullen, S. M., \& Rounds, J. (2005). Higher order dimensions of the big five personality traits and the big six vocational interest types. Personnel Psychdogy, 58(2), 447-478.

Muchinsky, P. M. (2012). Psychology Applied to Work: An Introduction to Industrial and Organizational Psychdogy (10ed.). Summerfield, NC: Hypergraphic Press.

Müller, L., \& Ruch, W. (2011). Humor and strengths of character. The Jaurnal of Positive Psychdogy, 05), 368-376.

O'Sullivan, M., Guilford, J. P., \& DeMille, R. (1965). The measurement of Social 
intelligence. Psychdogical Laboratory Report, 34.

Park, N., Peterson, C., \& Seligman, M. E. P. (2004). Strengths of character and well-being. Jaurnal of Social and Clinical Psychology, 23(5), 603-619.

Park, N., Peterson, C., \& Seligman, M. E. P. (2006). Character strengths in fifty-four nations and all 50 U. S. states. The Jaurnal of Positive Psychology, 1(3), 118-129.

Peterson, C., \& Seligman, M. E. P. (2004). Character strengths and virtues: $A$ handbook and classification. New York: Oxford University Press / Washington. DC: American Psychological Association.

Peterson, C., Park, N., \& Seligman, M. E. P. (2005). Assessment of character strengths, In Koocher, G. P., Norcross J. C., \& Hill III, S. S., (Eds), Psychdogists, (pp. 93-98). New York, NY: Oxford University Press.

Peterson C., Park N., Seligman M. E. P. (2006). Greater strengths of character and recovery from illness. The Jaurnal of Positive Psychdogy, 1(1), 7-26.

Peterson, C., Ruch, W., Bermann, U., Park, N., Seligman, M. E. (2007). Strengths of character orientation to happiness and life satisfaction. The Jaurnal of Positive Psychdogy, 2(3), 149-156. Rafaeli, A. \& Sutton, R. (1989). The Expression of Emotion in Organizational life. Research in Organizational Behavio, 11, 1-42.

Ryff, C. D. (1989). Happiness is everything, or is it? Explanations on the meaning of psychological well-being. Journal of Personality and Social Psychology, 576), 1069-1081.
Seligman, M. E. P. (2002). Authentic happiness. New York: Free Press.

Seligman, M. E. P., Steen, T. A., Park, N., \& Peterson, C. (2005). Positive psychology progress: Empirical validation of interventions. American Psychdogist, 605), 410-421.

Shin, Y. (2014). Positive group affect and team creativity: Mediation of team reflexivity and promotion focus. Small Graup Research, 45(3), 337-364.

Watson, D., Clark, L. A., \& Tellegen, A. (1988). Development and validation of brief measures of positive and negative affect: the PANAS scales. Journal of Personality and Social Psychdogy, 54(6), 1063-1070.

Wharton, A. S. \& Erickson, R. J. (1993) Managing Emotions on the Job and at Home. Academy of Management Review, 18(3), 457-486.

Wright, T. A., \& Wright, V. P. (2002). Organizational researcher values, ethical responsibility, and the committed to participant research perspective. Jaurnal of Management Inquiry, 11(2), 173-185.

Wright, T. A., \& Goodstein, J. (2007). Character Is Not "Dead" in Management Research: A Review of Individual Character and Organizational-Level Virtue. Journal of Management, 33(6), 928-958.

1차 원고접수 : 2015. 11. 30 2차 원고접수 : 2016. 03. 30 최종게재결정 : 2016. 05. 11 


\title{
The effects of interpersonal character strength on service employees' happiness in the emotional labor context
}

\author{
Sun-Hee Park ${ }^{1)}$ \\ Jee-Young Lee ${ }^{2)}$ \\ ${ }^{1)}$ Organizational Psychology, Seoul National University \\ ${ }^{2)}$ Graduate School of Defense Management, Korea National Defense University
}

This study examined the effect of interpersonal character strength of service employees on their emotional aspect of happiness. Interpersonal character strength has been shown to be a critical skillset required for service encounter employees, thus is expected to increase the levels of employee happiness, as well as to moderate the relationship between emotional labor strategies (e.g. deep acting and surface acting) that employees useand their positive emotion. The results from a sample of 129 receptionists working at imported electronics show rooms and service centers showed that interpersonal character strength indeed had a significant positive effecton happiness, even after controlling demographic variables and other character strengths. Furthermore, interpersonal character strength moderated the relationship between deep acting and happiness so that emotional laborers with high interpersonal character strength experienced more positive emotion when using deep acting strategy, as compared to those with low interpersonal character strength. These findings offer suggestions for organizations and their employees to develop both deep acting strategy and interpersonal character strength in order to enhance the level of happiness of employees.

Key words : service encounter, emoxional labor, interpersonal strength, character strength, happiness 